University of Louisville

ThinkIR: The University of Louisville's Institutional Repository

Electronic Theses and Dissertations

1941

\title{
The use of sulfonated alcohols in modifying alkyd resins.
}

Harold S. Sell 1919-2002

University of Louisville

Follow this and additional works at: https://ir.library.louisville.edu/etd

Part of the Chemical Engineering Commons

\section{Recommended Citation}

Sell, Harold S. 1919-2002, "The use of sulfonated alcohols in modifying alkyd resins." (1941). Electronic Theses and Dissertations. Paper 1895.

https://doi.org/10.18297/etd/1895

This Master's Thesis is brought to you for free and open access by ThinkIR: The University of Louisville's Institutional Repository. It has been accepted for inclusion in Electronic Theses and Dissertations by an authorized administrator of ThinkIR: The University of Louisville's Institutional Repository. This title appears here courtesy of the author, who has retained all other copyrights. For more information, please contact thinkir@louisville.edu. 
THI UNIVHRSTY OF LOUISYILT:

2HE US: Of SULF

III

HodrFING ALTID REsing

A Thealu

Subnitted te the Fearty

of the Graduate Sohool

of the University of Loulevi210

in partial furtilinont

of the requiremente

tow the dogee of

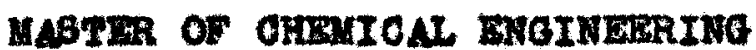

Departanent of Chemleal Ingineomins

by

Rarola s. Bez2

1941 


\section{THE UB OP SULPONARED ALCOHOLS}

\section{III}

MODTrImG ALRD RRSIMS

Rareld $\mathrm{S}$. Soll

Approved by bxamining oomat tee

Director $\ldots, \ldots, \ldots \ldots+\ldots$
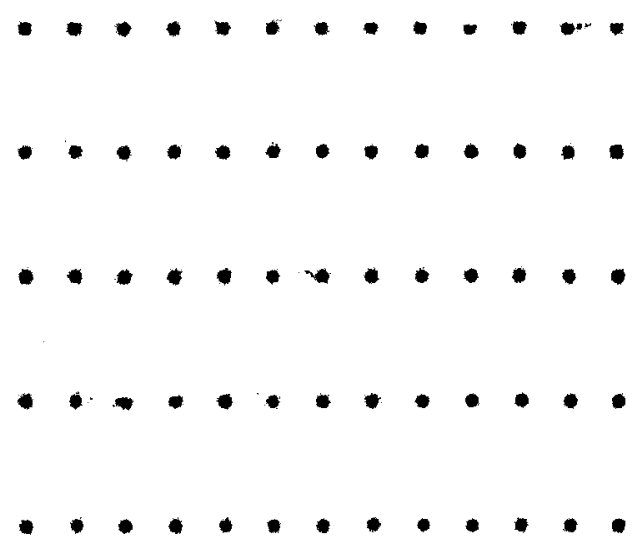

May 15. 1941 
TALI or conimis

Dase

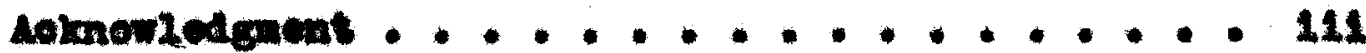

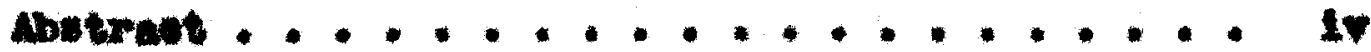

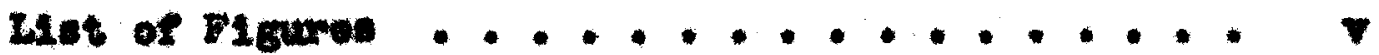

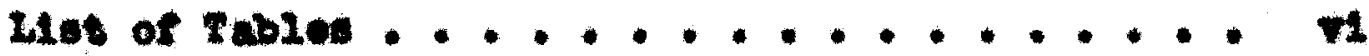

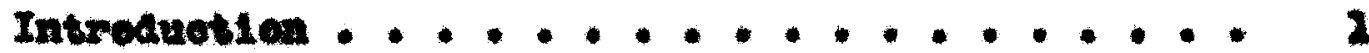
Itserater......................... 5 Thearoteal ....................... 12

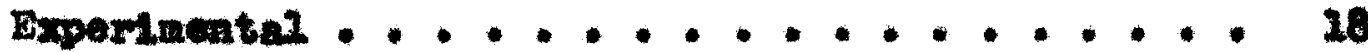
Heterlal . .................... 19 Aporatur ...................... 23 Broochum ........................ 20

Dote and Rovares ...................... 5

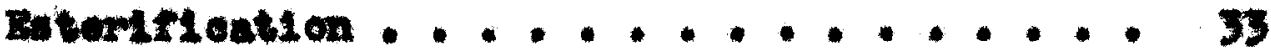
Geolars rino ..................... 3 atar ............................ 3 Meranere ........................ 3

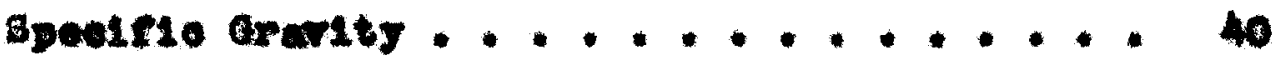

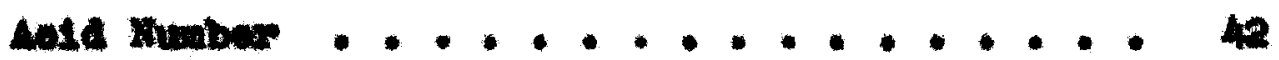

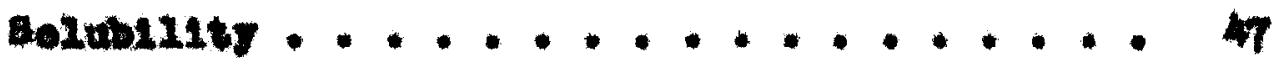

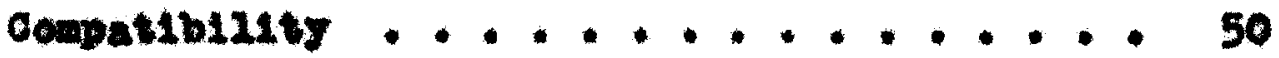
Lagquer ApplioatLoa .............. 54

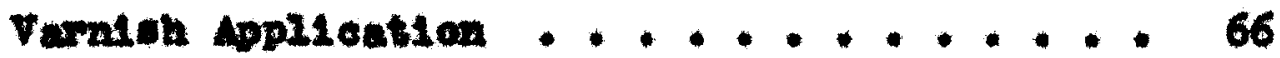


TaLs of comrang $($ oon't)

pase

Intorprotabioa of Reautt. . . ......... 69

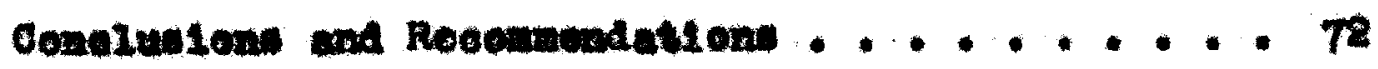

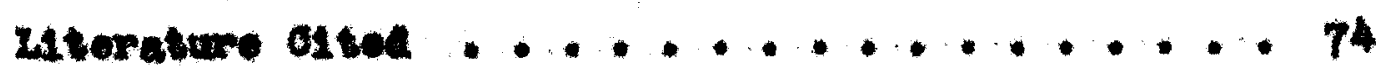
Aorrondequmb ................ $\mathrm{T}$ Vita .......................,78 


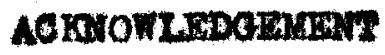

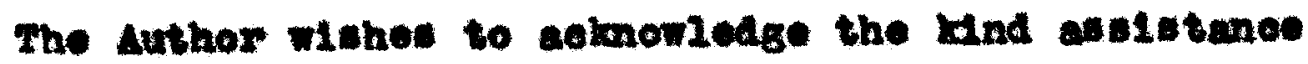
and holptul guldanoe of Bx. B. B. Litkenhou, who alreoted this rosearoh. 


\section{ABSTRACX}

The purpose of this rosearoh was to inveetigate the orfoote of modifying glyoorol phthalate realn with high meleouler welght sulfonated aleoholo.

It wat found that an the wodiricatien of the eikgt

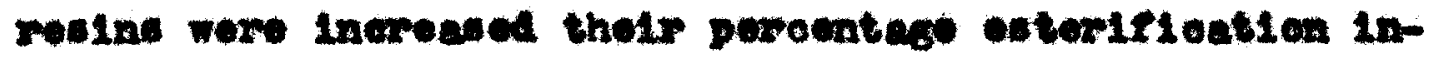

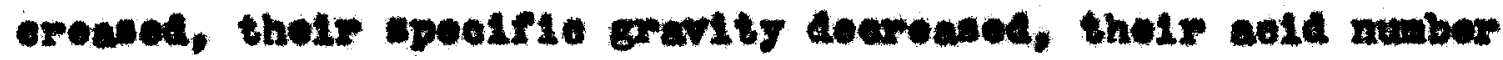

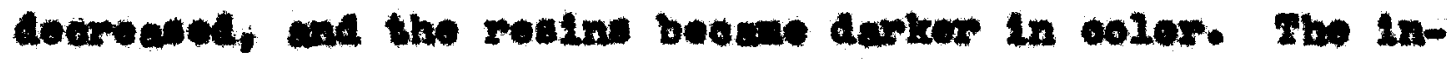
corporation of the sulfonated aleohol into the alkgl reain

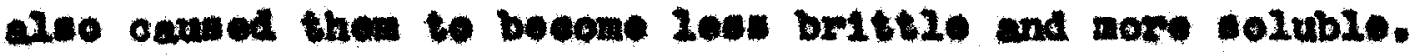

The wont Inportent afreet of the modifloatlen we the merlued Inerease in compatibility of the realns with nItroodIulese, waking posalble the we of tho rosins in nitrooelluione leqquer formulation. The greatent ponsibility for applioation of the sulfonated aloohol modifted ally roulns Ites in the Fleld of nttroesluniose lacquers.

Beswies the realn st121 rotalned their oll incolubility won mea bodstied, thor had no vamish opplieatson. 


\section{IIST OF FIOURES}

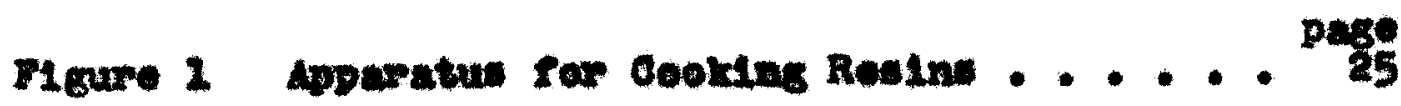

Mgure 2 Peroent Evterifloatien v. Welcht

Poroont Modirloablon ......... 35

Figure 3 Speeteie Grevisy w. Wolght Roroens

Mocifloation ............. 42

Figum 4 cale number vi. Woight Poroont

Modirtostion ............. 44

Figure 5 Solublilty ve. Welght Poraent

Modriontion ........... 49

Figue 6 Trilinear onart for 30.2 Wt. Peroent Modiried Resín.......... 62

Figure 7 milinear onart for 38.1 Wt. Percent Modiried neatn ........... 65

rigure 8 Variation of Lequer Froportied .... 71 


\section{IIST OF TABLES}

page

Table I Foroont Ifterifloation vi. Wolght

Poroent Molification ........ 34

Table II Bpocifie Grants ro. Wotght Rereont

rodirteasten ............, 40

Table II Mald Value re. Welght Peroent

vodifloation ............. 43

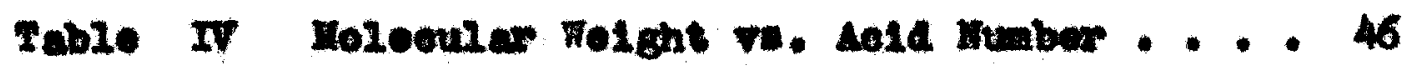

Foble, $Y$ Solubility w. Nolght Poroent

Modirieatiea.............. 48

Table Vt Copatiblits va. Welght Peroent

Dolincatien ........... 53

Table VII Leoquer Iroportien vi. Inoquer Con-

porition for 30.2 Fe. K Modiried Resin 61

Table VII Leaquer Properties ve. Lacquer Com-

position for 38.2 Dt. 8 Yodifled Resin . 63-64 
IMTRODUOTIOA 
Foh yea the protective ooating industries conctue 1urge poroontage of the realns produed for use in

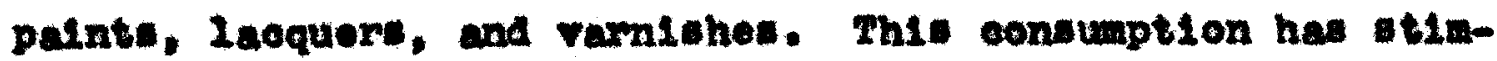

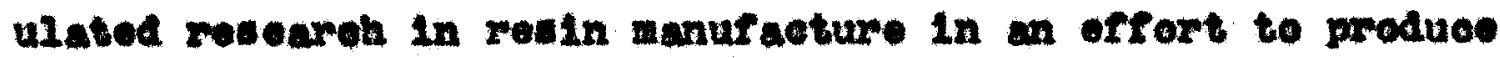

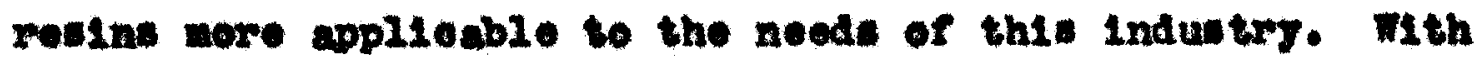
this noed In wind 1 wa thought that inooxporation of sul-

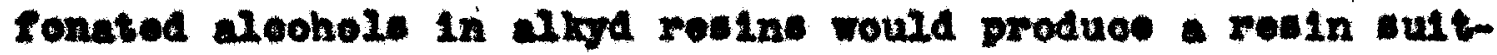

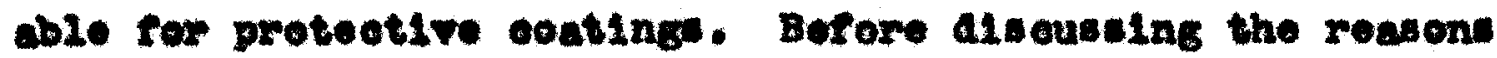

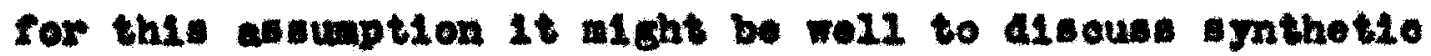
rosing belora.

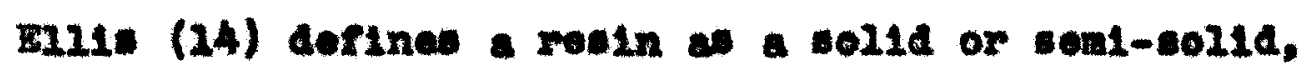
complex, anorghous alxture of organte cubetanoos, harting no

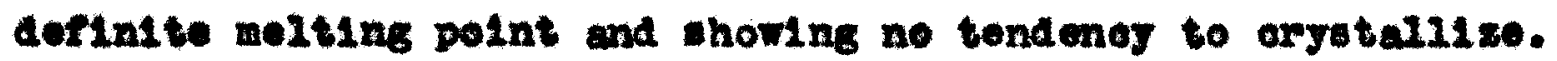

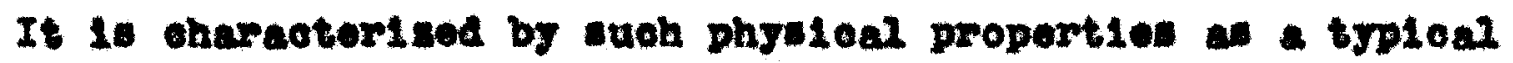
Iuttor and concheldat rraoture rather than by any derinite ohouleal coapositien. Rosine tueh as rosin oocur in nature and are inom a natural resine, but within the past fow joar

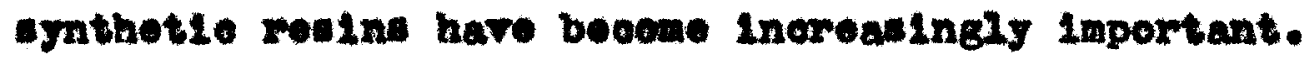

Under the term agnthetio rosine 10 a groming group

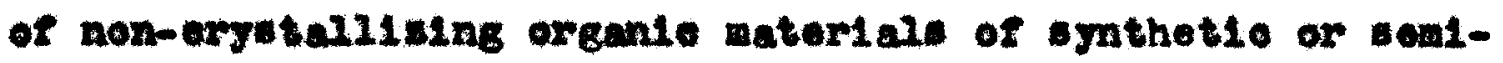

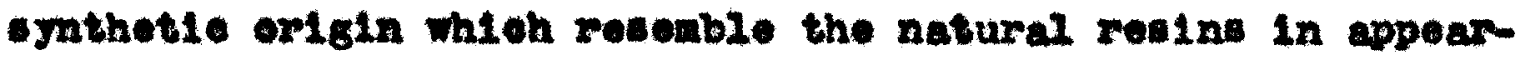
anos and properties. These sytheste resine atride into two alasest those whob sexve an plestos and those used as 12 . forming abbtanoes in vamiches and othow proteotive ootingi. 
Resin: for ume in the coating Industries must be hard, Noluble, roditsant to rater, and durwble. Mthough thore are uny alfrome types of symthotic resine used in protectite coating ong the so-onlled alky trpe was consldored in this researoh. Migh rooln are resine produced by the reaction of poljhydrte alcohols and poifbasio wolde. If the resettve groups in the deobol and wold are in the rat1e of 2,2, hard rouln do not reault, but if the roaotive

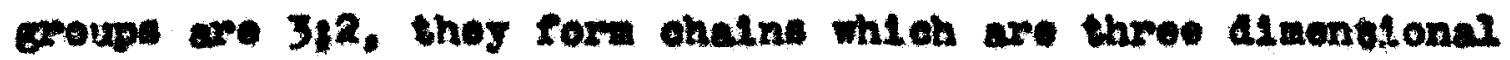

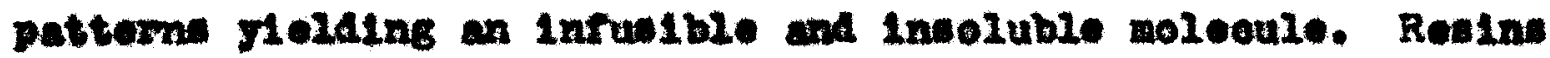
formed by thi. latter rogotion are usvaliz too insoluble and too brittie to be uned in rarnishes and lasquers: and rarlous other aelds, aloohols, or olle mat be incorporated inte the realn to obtaln the denired properties. Algd resin: hare beon modifled with butyl aleohol, oastor oll (26), Iinseed 011 (19), Iactie aeld (30), and nonobaste ubbtanoes (6) to obtaln useful realne. The presence of those monobasto selde and aloohole hinder the IInkage of the ohaln: produelng inareased solubility, Inoreased rioxibillty, and deoreased brittionoss.

In this thes1s work a high molooular wolght sulfonated aleohol was inoorporated with the alky rosin to make a rosin ultable for use a apotective costing. The sodium salte of oulfonated wloohols are belng weod at present as leturgents, wotting agents, and "soapleae" boaps. The ubstanee 
consists of a wifonated high moloouler wolght aleohol, harling catd sulfate croup in place of the hydroxyl group.

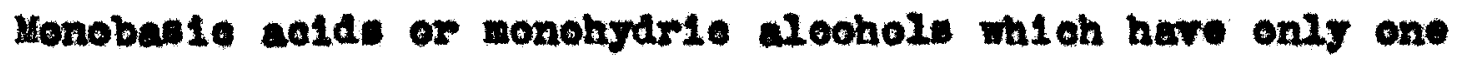
reactive group to not give rise to resinous natorials, but Ineorporation of hydrophyile wroup wheh at hydroxyl or sulfonte groups tond to produce water solubility and conpatibl11ty wth nitroeeliulose wile long pararrin-11 we ohain inerease the oll solubility.

The ulfonated alcohol $\left(\mathrm{ROSO}_{\mathrm{g}} \mathrm{H}\right)$ alfrors from the sulfonie aold $\left(\mathrm{RSO}_{3} \mathrm{H}\right)$ only in one oxggen atom whioh auggeste that they might produce somownat sinflar orfects. Sulfonle colds in genoral are used as eatelysts in the manufaeture of alyyd rosins (9) (a), and noutral phenyl bensone sulfonate (10) has been used os a pleatleisor wh gljeerel phthalate resine.

The purpose of thi Investigation was to determine whother the realn formed by the roaction of the alkgd resin and sulfonated aloohol would produoe more soluble rosin, hard but not britt2e, Mexible, and suttable for use as a rarniah or lecquer roaln. 
HISTORIOAL 
Synthotie rosin anufacture is a rolatirely now t1eld of chenistry. The prinolpal motive in oreating sythet10 rasins was not to inltate the natural products, but to $1 \mathrm{~m}$ prove upon then. An userul as the natural resins are, there 14 not one that 16 entirely perfect, and all of them have fanits wiob should be ilininated.

The firet acoount of agnthotio resin manufacture was In 1901 when Fateon Silth (32) dicoovered wh1e worling wth elyoorel and phthelle anhydride that they did not form - elaple ester on roation as bo hal expeated, but rathor a rory hard traneparent col1d. Sinee the discovery of this reastion between glyeerol and phthalle anhydride there have boen many invostigations inte the wohanten of resin formation.

R. H. Klento and A. G. Hovy (26) in atudying the rate of estorifleation of two nols of byjoerol and threo mols of phthalle anhydride found that the roaction procend rapld27 at first rlolding within one minute, at the temperature Inventlgeted, a produet oorreaponding to $50 \%$ esterirteation. When the esterifteation is about $60 \%-70 \%$, the rate ralls orf but proced nore lowly up to and berond the point whore gelation eoourn.

The prelinlnary formation of the monoseters was noted by Honel (18) who found that the continued heating of 
the Infugible realin after golation deareased ito ability to well with solvente Indeating the procen of esterifleation. Ho ooneluted rosinifloation was a formation of oompound of kigh noleoular welght wolely by contlnued octorifloation of

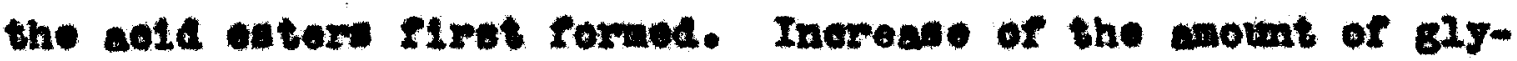
corel cauned the acte number of the mixture to deorease unt1I fincily the Infulbio state oould not be roached. He also found that when glyeorol and phthalde anydride wore taken in wh proportion to form wone- or diesters and heated, the reaotion prooveded rem showl at $160^{\circ} \mathrm{O}$. Dowe $230^{\circ} \mathrm{C}$ homever, the reaction wal nore rapla, but the tendenoy was to rom hand resine.

Th1s rocotion between dibanto aelds and polybanto aloohele wes mown for a number of year,, but 16 remalned for the Inargiration of the leqquer Industry to stimulate roseareh on the preparation of reatin. whion would be compatible Wth nitrocellulose to produce a durable lacquer. The developuent of synthotie roolns of the alkye type suppiled the laequer Induetry with an alequate conres or realnous material and was in part instmuental in alding the rapia oxpenoien of this Induatry.

The pure elyeorol phthelate resin is in all cases too insoluble, brittle, and infuetbie for use in rarniobos or laequers, and ramious plestlolsers, elther In the form of soft realn or 11quids, have been ineorporated Into the alkyd 
resin to Inport ite properties.

M. J. Callehen (8) and T. S. Arsen (1) used suoolnio bijoeride a a plestelser. The disadrantage of uning the glyeerldes of aliphatle dibale selds to inorease the 110xiblilty wat that the offoet was not pexmanont. Thon hoated for a long tine or when aged, the mixed realn bedane bxittie and tonded to have a high acta aumber.

Kenis and Rohlf: (27) suggested the inoorporation

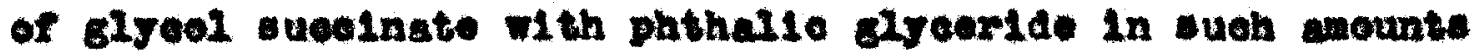
that the compeition oured when heatod a a high teaperature. about one aol of each realn way be uBed. The resins way be prepared separately and then mixed or all ingredionts heated cogether at $180^{\circ} \mathrm{C}-200^{\circ} \mathrm{c}$. Curing was carmied out at $150^{\circ} \mathrm{C}$ and sort flexible product was obtained.

High bolling solvente wore used to Inorease the nexibility by Conover (22) who mixed 15 parts of diothy phthalate with 85 parte of frounly prepared phthalio glyoeride and heated the solution te $150^{\circ} \mathrm{C}$. A wert 11 ght solored restr was obtalned mieh has boen oonvembed into a floxible infusible form by heating to a high temperature. R. H. Klenze (28) used abutyl phthalate, triphenjl phosphate, triacotin, or anliline to everoome the brittlenese of the alkgd reain.

The oddition of furfural inoreases 2lexiblilty but hav the tendeney to arken the eolor. Conover (12) hoated a 
mixture containing 92 parte of eljoerol, 148 parte of phthalle anhydride at $210 \%$ for on hour allowing the temperature to $\mathrm{fall}$ to $140^{\circ} \mathrm{C}$ and added 48 parts of furfural, produoling cort, dark colored mass. Thle produot was converted to the Infualble form when heated, the corrorsion belng about ten times as rap1d as that of the rosin in the absenes of furfurat.

Blue oolored resin: of lmproved weohentoal and electrioal propertie can be fowned by the addition of anino oarboxyllo aolds (34) at any otage berore the converalon of the resin to ito Iinal form.

Harder and more rosiotant elycorol phthalate roalne are prepared by treatment with keteno. The free hydroxyl groups in the elyeorol phthelate realn wore aeotylated under these conditions. The produot thu rormed was carkor In color and had a highor add numbor then the original resin but was more resistant to water (7). The ketene treated reIn was compatible with nitroeellulose.

A great many other wodifying agente have boen used In the realn molecule for the sane purpose or to produce roins of alferont properties. Tho modifleation of alkyd reIns with monobag10 aolds Imparte Inoreased solub111ty to the resin. Aliphatio solds (butyrio, acot10) have pronounoed softening ation. Aalds from non-drying olla load to the formation of produote of greater Ilexibility. As a 


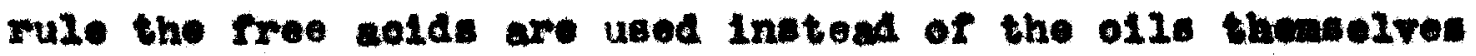
since, With the exoeption of castor o11, It is alfrieult to Ineorporate the glyoeride o110 into on alky resin unlose direot methods are used. Other monobasts alls used it th alkyl resins inelude natural resine whith inorease the colubli1ty and brittleness of the rowulting resin.

Other Induvtrial modifring agents for the pure alkya rosin consist of monohydris aloohols (5), ketones (13). and varlous o11.

The prineipal we for all of these modirlod alkga reains has been in coating compodition, partioularily nitroealiulose laoquers. Fren those previous investigations it was aupposed that the inoorporation of the sulfonated aleohel Into the alkyd realn alght produoe a realn applicable in the proteotive coating industry. 
THEORETIOAL 
The rules for resin formation of polybasio acide and polyhydrte aloohole glven by R. H. Kionle (23) arat

(1) Hgh moleoular welght organio oompounds are rormed only wen the interlinking moloculos are poly-roattive.

(2) The Interinking of the moleouled proeed acoording to the thanee contaot of any two roactive pointe.

(3) The relative ise and whape of the reacting welecules and the posttion of the reactive polnte largely dateraine the phytioal propert1os of the reaulting pelymer, suoh as, hamnow, Roxibility, and heat convertiblily.

Eaterifloation of a poljbario acid, suoh as phthallo anhylite, and polybasio aloohol, such as glycorol, loses to high moleaular welght produati instead of the pure ester. In tuayling the reaction of glyeorol and phthallo anhydride. R. H. KIenle and A. O. How (25) found that the roaction proeeced by esterification with water and the resin as the only producte. No intermediate aldehyde was formed. They stated that the reaction, when carried out at a temperature at whlob both roatante were 11quid, wont rery rapidis at the atart crolving heat, and was apparentis half complete within one minute of mixing. This reaction corresponded to the formation of the monoester of phthalle aold. 


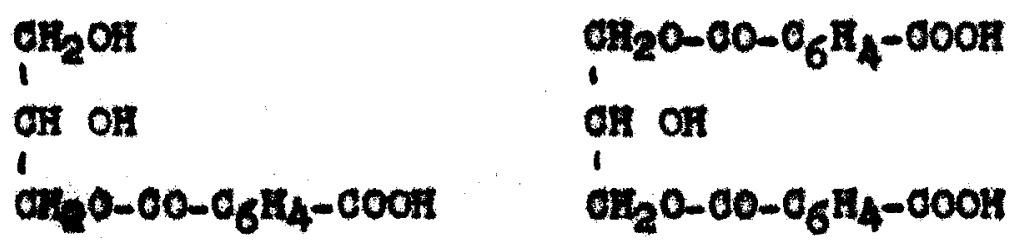

Mocorline to Hönol (18) the Intornal esterifleatlon wa responible for the formation and oharaeteristio propertios of the alkge rosins. Ho roganded the firet stage a fiving rise to alxture of the mono- and diglyoerides reforred to previous15. W1th furthor heating these react to give condensation product as follows:
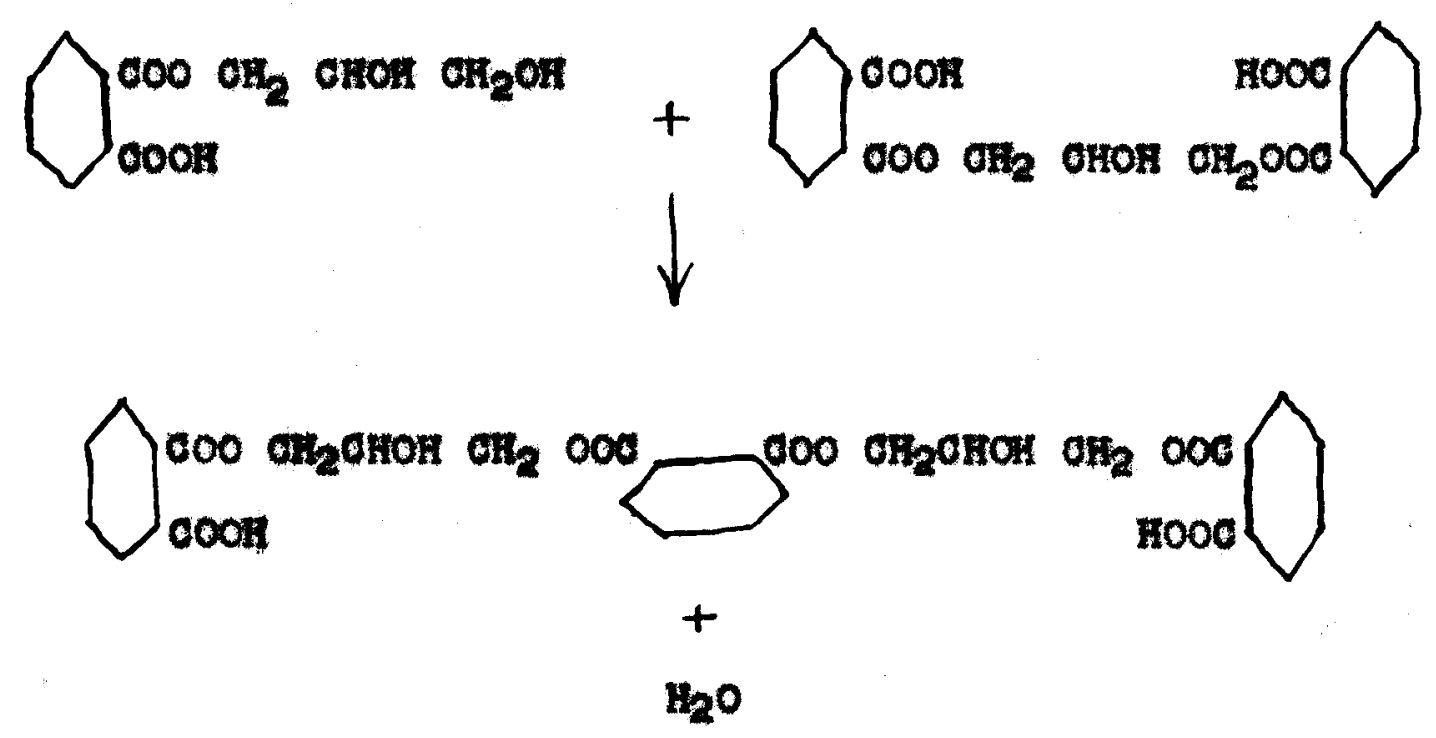

Kienle and flow (26) alwo tound that at the reaction procected under Isothormal condition, the free coldity atoreased and the porcent exterification and sow point increased. The variation with time ras quite irregular although there was a derinite trend upward in the reaotion. 
The resin wa eloar, coloxlous, and sranparent, and remalnod so to the ond of the roaction then 1 resombled glass.

Sohlenker (31) thought the rosin wero 20 g ohatn of glycerol aoleoules linked the alpha posttion through oarboxy groups of the altornating phthalle acta moleoules. wile the beta hydroxyl group wore esterified in Iater stages of the reastion.

Acooxding to $R$. Houwlink and $K$, H, Kaasone (20) only the alphe hydroxyl group of the glyeerol are active beIow $180 \%$, wat at higher temperatures the beta hydroxy 1 groups onter into the reaction with the rormation of a throe dimontional polywer. Further eaterifloation now involving the beta hydroxy group might proood intornaliy, forming suoh a elyeoride.

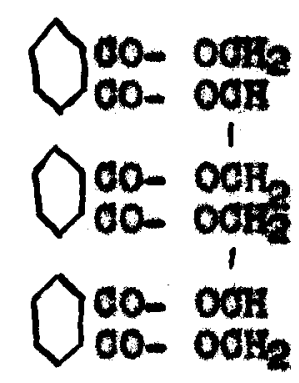

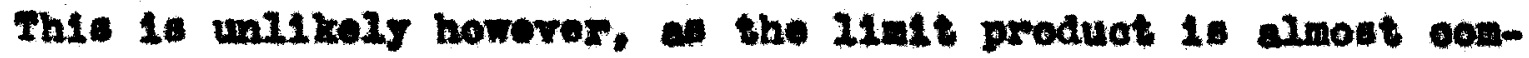
pletely coluble in very dilute xoH, requiring in faot only as muoh alkall as is required to noutralles the free sold. The progresalve deorease in adalty and corresponalng inorease in resinlike propertios can, horever, be far more really ex- 
platich by exteriftoation of a hyarexy croup by the ourboxyl group of unothor molesule.
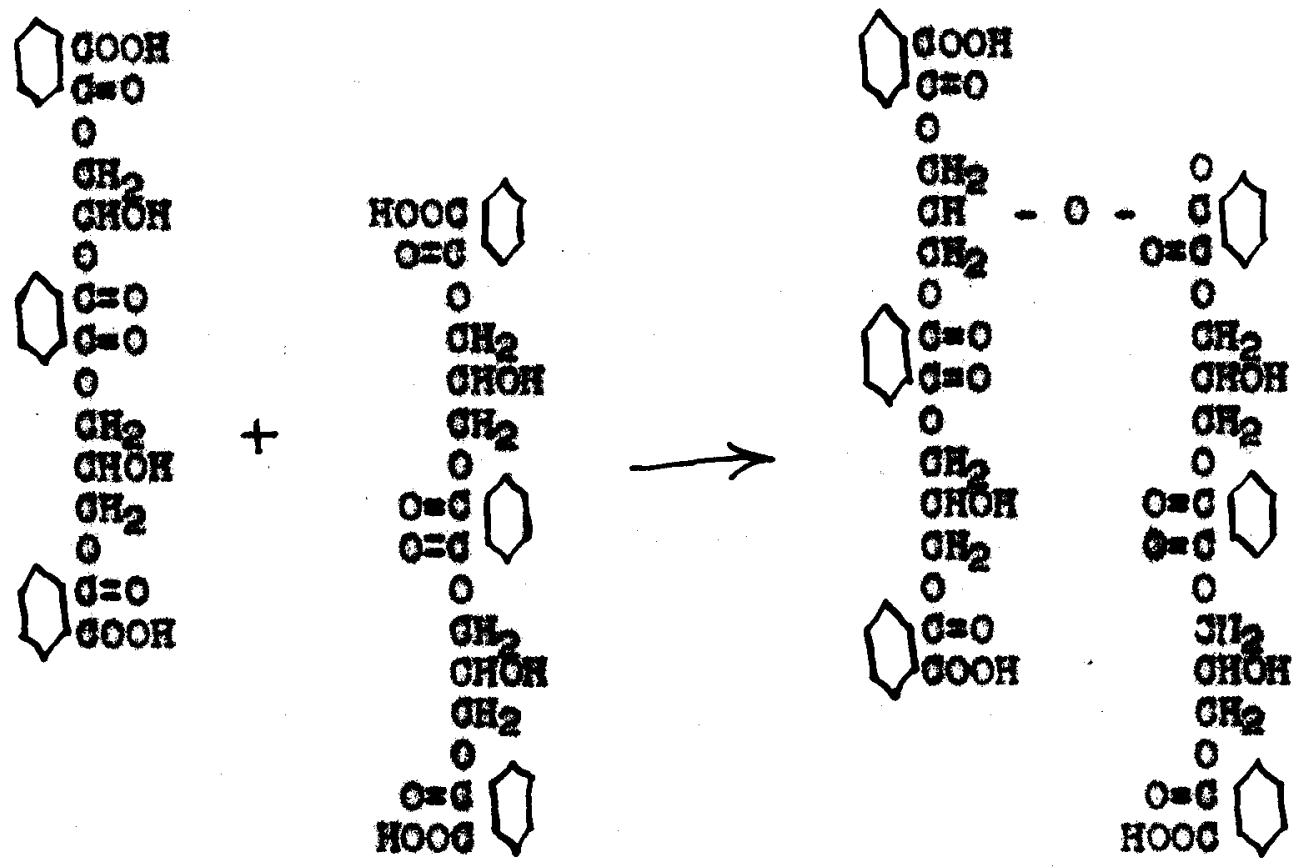

The centinuation of this astorification rosults in the forwation of large moleouled contalning long branohed chaine of the type chom, which perhape rurther condense to ring struotures of higher ardor. The length of woh ohatne and the correspondiag oblleldal properties of the rosin dopond priner12y on how long the hoat sroationt 18 continued beyend the point at whiok internal osterifloation comenoed. It san be seca that sotorifioation can also take place on the other oarboxyl groups of the acta in the molocule as well all the beta hydroxyl group, forming a leng ohatn of linking aola and aleohol moleoules, the length and molecular welght of 
whioh aro dependent upon the degree of complotion to whith the rocetion was carried. No the alse of the moleoule beoomen greater, it also beopmes more complox and more compat with the reeult that the colub111ty and fusbility deorease.

The realns have been elaesifled by T. Hedly Barry (4).

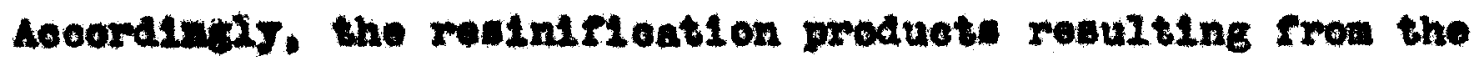

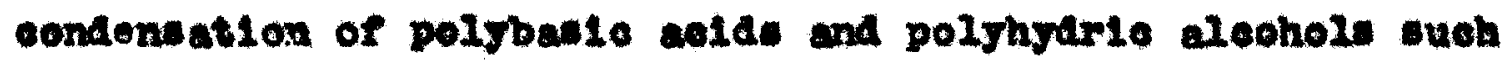
a glyoerol and phthalle anhydride way bo elased in stages all A-btage wich is tustbie, solublo in acotone, and not roalstent to wator. It is converted to B-stage which is rus1ble, Ineoluble in aotone, and not resietent to rater by hoating. This is furthor converted by heat to c-etage whioh 1. Infunible, insoluble, and resistant to water.

Substanece which have only one rogetive group woh as monoball welds and monohytar10 aloohole, or the sulfonated aleohol used in thie researoh do not give ribo to resinous materials. Inoerporation of those ubstances prevente the oress linking of the noleoules by deareaning the number of posalbilitios for resotion, and in goneral ouses the resin to beome wore voluble and fuslbie. Whon a modifying agent 1. Incorporated inte the alky resin, the posalble structure nay be ropresented as!

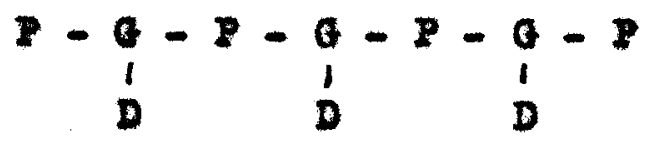


In the strueture, O ropresonts a dreorel moleoule with the three hydrogen: of the hydroxyl groups replaced, I repreaents the phthaly radical, and D represents the modifying agent. If less of the modifioant is used, more of the glyoengl rad1oale tond to unte with phthaly groups thus approsehing the atruature of phthalio elyooride.

The offeet of eonduoting the reation at a higher temperature was to reduos the emount of free acla more raplaly then at a 10wer texperature. The temperature and time nocessary to reach 95\% ontoriflation ueing stotohlonotrie proportlome of glyoerol and phthallo anhyaries was 1000 minutes at $290^{\circ} \mathrm{C}$ and 220 mimuten at $220^{\circ} \mathrm{O}$ (25). Sh1geru Hixano and Illinewuke Ohash (17) roported that one mol of glyeerol and one and ono-hulf wols of phthalle anhydride whon reacted at $200^{\circ} \mathrm{C}$ went vory fast at rimet oorrosponding to one-half roaction. If the sane quantitien were heated at $180^{\circ} \mathrm{C}, 200^{\circ} \mathrm{O}$, and $220^{\circ} \mathrm{C}$ the reaction beoane fawter, but 221 the resine formed hot the same aeld ralue and coftening polnt. Stiffoning

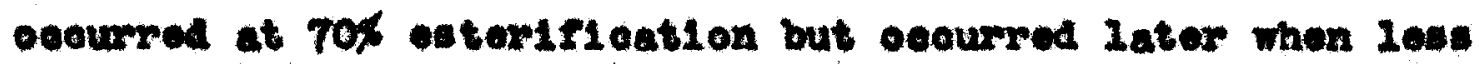
phthallo anhydride was used, and no otiffening ooaurred be10w .88 wols of phthalle anhydulde. 
BXPERTMTHTAL 
HATRINS

The coures of the curfenated sleohol usea in this peaearoh was trom the Proeter und Gable produet "Droft". and the colsate Pernolivo Peot product "Vol". Both produote

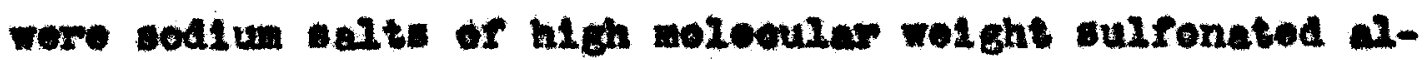

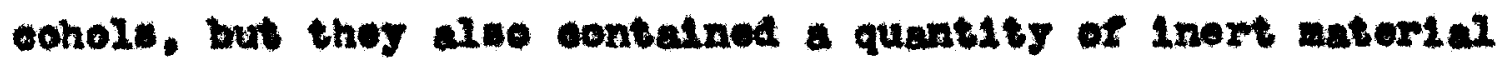

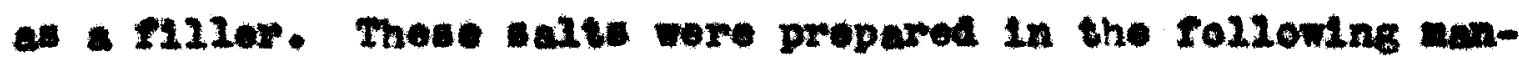

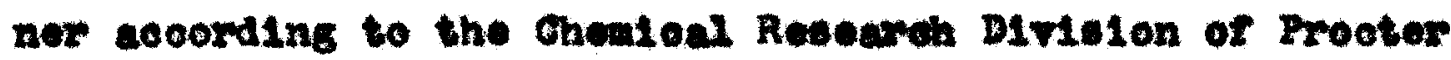
and Camet

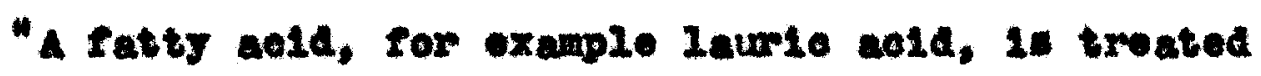

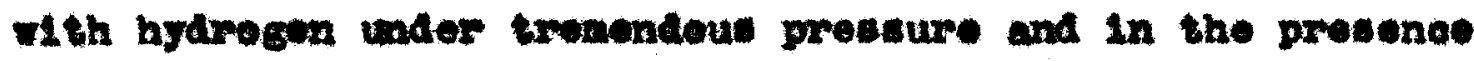

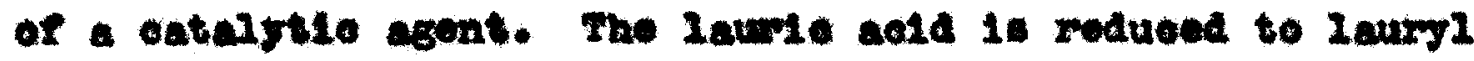
reoke1.

$$
\mathrm{CH}_{3}(\mathrm{OH})_{20} \mathrm{OOOH}+2 \mathrm{H}_{2} \longrightarrow \mathrm{OH}_{3}\left(\mathrm{OH}_{2}\right)_{20} \mathrm{OH}_{2} \mathrm{OH}+\mathrm{R}_{2} \mathrm{O}
$$

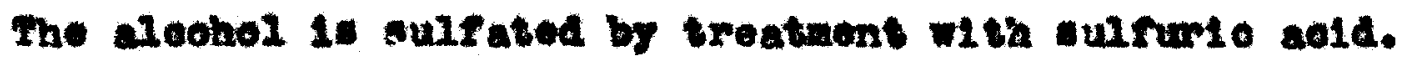

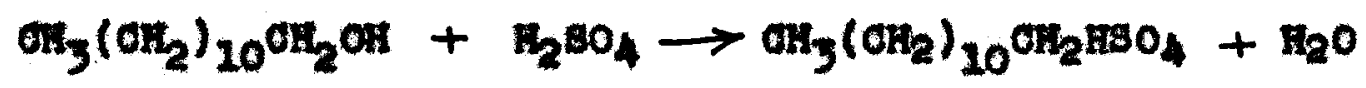

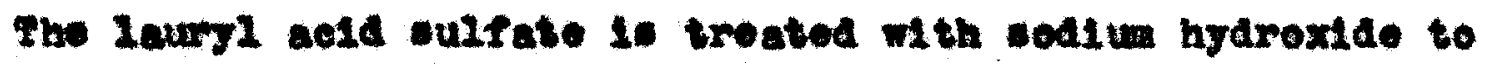
rom the noutral cadim ealt.

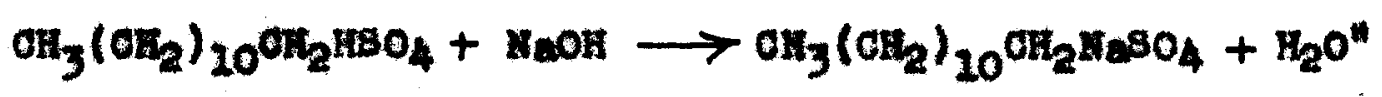

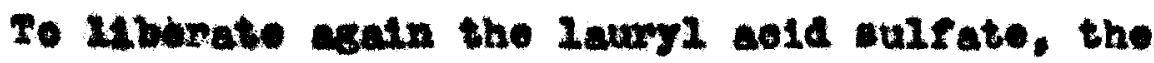
coliu ant hes onig to be troated with a alute hydre-

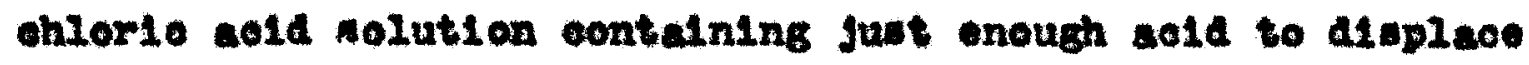


any equilibriun tending to hydralyeo baok to leurgl aloohol and sulphwrio acte.

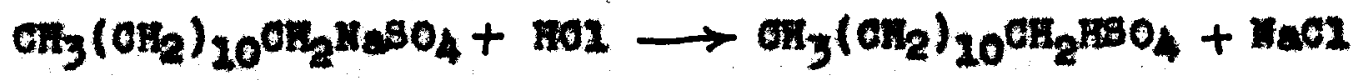

Rure lons ohatn seld bulfates wero not arallable - suoh because the 2014 was sowewhat unstable and ookla not be kopt for a long poried of tiwer bet the oompound was very utable ane codiun oute.

47. I5. E. Dreger, Alrestor of researoh of Colgate Palnolive Reat Co. In Jorsey C165. New Jerwoy, wote that "Ve1" we the sediu alt of the sulfated nonoslyeoriden of oocomut ofl ratty aelds, and the oomerelal produot oontalns $35 \%$ to $36 \%$ activ ingredient and $64 \%$ to $65 \%$ vodiu sulfate 11210x. This was in reality a long ohain of oarben atows containing the acid alfate croup on the remaining two hyaroxyl groups of the gijeerol.

In toat rum it was found that the eurfonated aloohol extracted from "vel" was more stable than that extracted frem "Dreft" and reacted in the rosin nixture wore readily probably beouse of the presenoe of the glyoerol base. Pure sodium laurgl culfate was obtalned from dupont under the trade name "Duponol" and oontalned no fller whateoover. This had only to be treated with the dilute acla to separate the pure laury 1 ald sulfate. The extracted produot was more unstablo than the eulfonated glyoerol oater and decomposed much wore 
roadis on heating.

The extracted sulfonated aloohol rrow "vol" was a brownth olly 11qute whloh wa coluble in water forming a poaplike colution inglar to that of tho soditu calt but by using lares anounte of the codiun alkgl sulfath in mall volumes of water and aturating the colution with alt, the acld wulfate was soparated. By waxaling the solution curing the alting out, the ompenents were separated nore readily. Since the sulfonated alconol solldifled when 00010 sllghtly below room ceaperature, It could be meparated and purifled by a process of rreosing, removing the 11quid portion, and remelting.

Cooenut 011 ratty cold has a denelty or .843, a molting point of $62.6^{\circ} \mathrm{O}$, 10 insoluble in wator, and decomposes when heated to a high temporature. Gijoorol has a donelty ot 1.26, bol1s at $290^{\circ} \mathrm{O}$, is very celuble in water, and welts at $27^{\circ} \mathrm{C}$ but wolidirlo at a wueh lower temporature. The tulfenated product of the monoester of ooconut oll fatty aeld and the glyewrol had tho rollowing phyoloal oonstantis.

$\begin{array}{ll}\text { Color } & \text { brown oll } \\ \text { Donsity } & .971 \\ \text { Kolting Point } & 26^{\circ} \mathrm{O}-28^{\circ} \mathrm{C}\end{array}$

Then this product was heated in alatiling flask, it dooomposed orolving water and yollowioh greon 12quid. This 11quid, 
Which was rery insoluble in water, alstilled trom the flank and loft a gang black residue.

The other compononte used in the cookdng of the

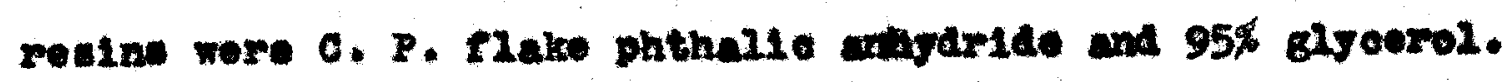


APR ARATOS

A1 the realn were cooked in a $500 \mathrm{ml}$. three nooked rlask sot in a constant temperature 011 bath so that the temperature of the reaction oould be maintalnod al conctant as possible. $40^{\circ} \mathrm{O}-360^{\circ} \mathrm{C}$ thermoneter alpped into the reaction alxture through the eenter nook and rooorded the temperature of the reaction mans. A hand at1mer wiso fit around the thermometer and oame through the center neok. Th1. was operated in on up and down motion perritting atirring of the reation mast.

A Ien strean of carbon dioxtde gal from a tank of eompreased oarbon aloxide was bubbled through the rosin during the rosotion to provide an inort atmosphere and provent any oxidation from the alr. The gas was lod into the rlak through a tube in one of the sall neoks, the tube alpping Into the reaction mixtire and also serving to remoro small anples of the cook onto a glase plate for testing purposes. The other sall neok vas equipped with a water oondencer to ooniense the water orolved in the reaction of the glyoerel, sulfonated aloohol, and phthalle anhydride. By moasuring the water evelved 1 was possible to follow the progress of the reaction.

The 011 in the 011 bath conpletely covered the rlakk to prevent the water of reaction from oondenelng on the aldes 
24

of the flask and running back into the resection mass, In this manner most of the rater of reaction was removed from the flak. The carbon aloxice also helped to carry the water vapor trow the Mask and added in the agitation of the resin mans.

The sources of heat for the oil bath was an elootrite pad or a bunsen burner. 


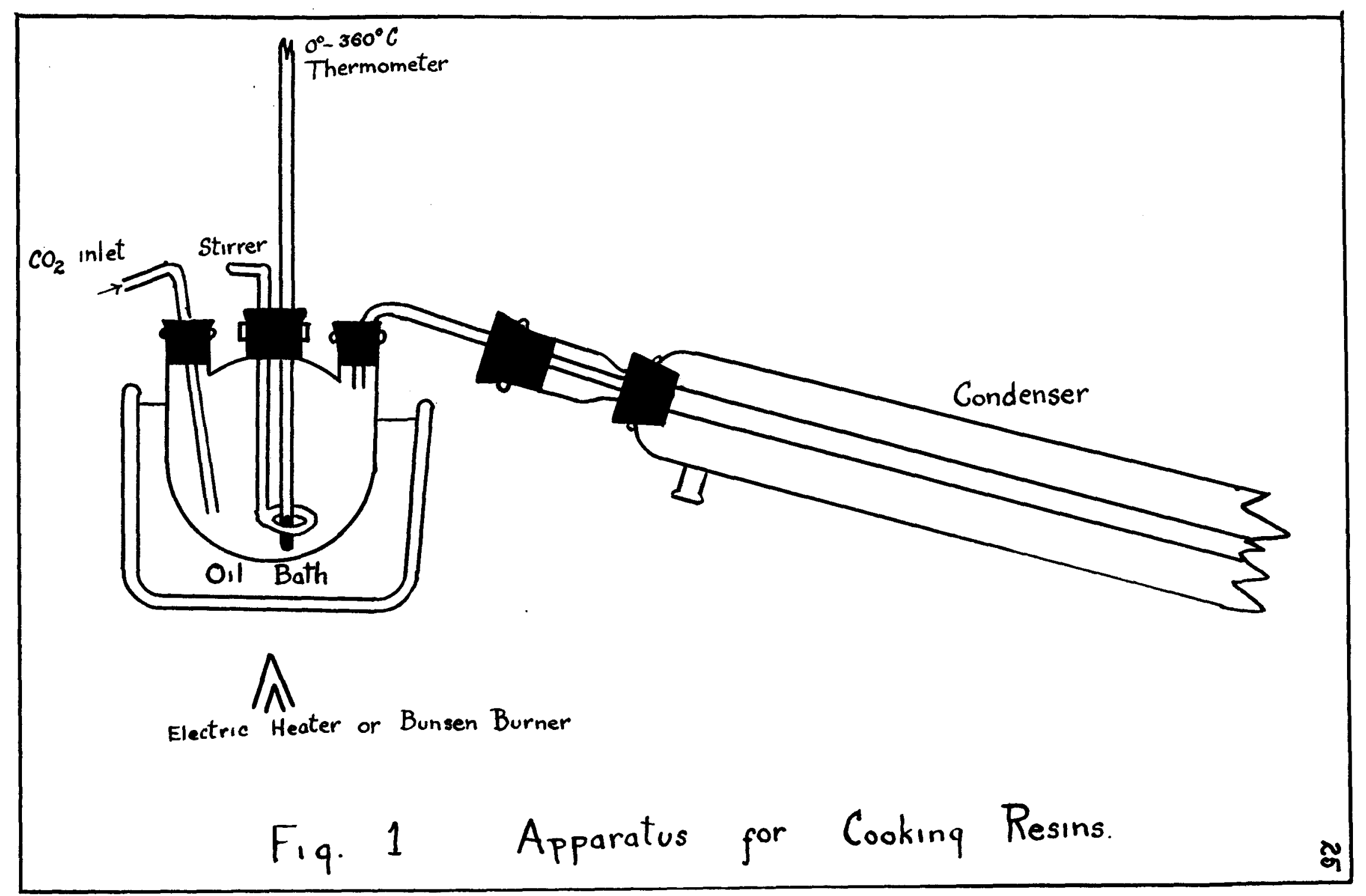


Frooswati.

All the roalne wore propared in the apparatus provoudy doseribed usling a constant temperature of $200^{\circ} \mathrm{C}$ for

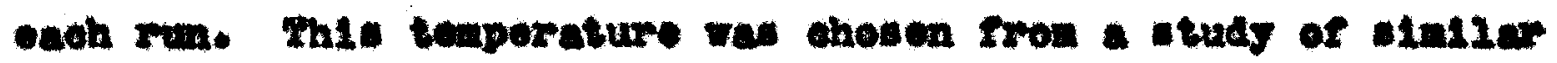
rugin roatione in ordor to determine the beat rosotion toupcrature. The range of temperatures genorwily uned in the

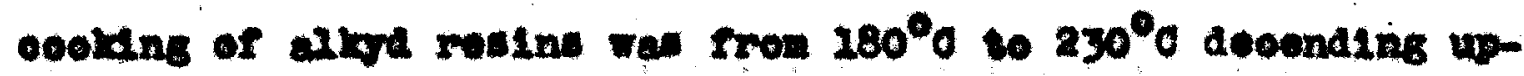
on the epeed of resatien desirva. A rathor 201 temporature was shosen to alninlse the poundbitity of any acoomponttion of the sulfonated cleohox. The resin wore all oooked in an Inor atmosphore of oarben dioxide to prowent any oxtadition frem the alr and to obtaln the lightent colored realn poe-

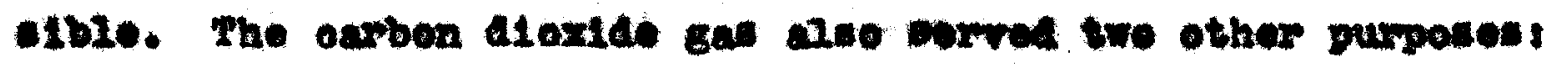

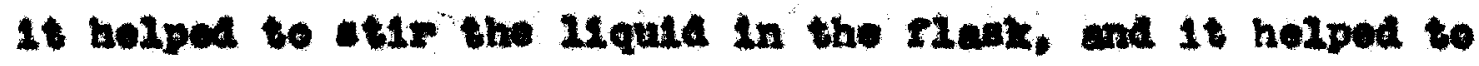
anry the watar of roation from the rlakk.

The throe oomponents of the roain wore placed in the reactien Rakk at the start of the run, and the teaperature we raised to and bold ot the roation tomperature un112 the sook was comploted. Extreme oare had to be taken in cookding the redin becued the aulfonated aleohol and rouln

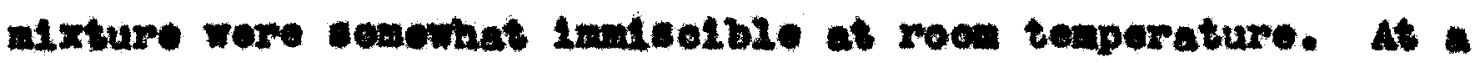

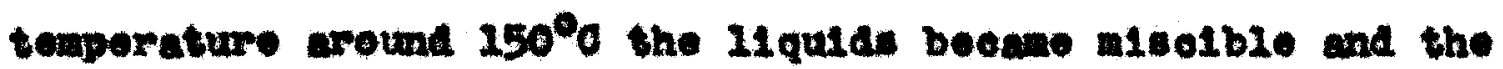
mixture reactod. The carben dioxide inlot tube oerved to remore snall saples of the resin from the nak at definite Intervalas shese samples wore plaoed on a glase plate and 
wlowed to cool in order to deternine how the reaction was proescdirg. At the outact of the resction the cooled teat drope of realn had a loudy appoarance, but as the ronetion progresed the drops becand 10se oloudy unt11 at the ond of the eook the roeln had a olear appearance. All the culfonated loohol mus be reacted or removed from the mixture bePore the resin thloken, or the compononte upon coollng will

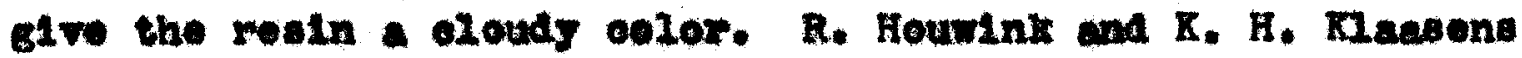
(20) Gtated that only the alphe hydroxyl groups of the glycorel are set1ve below $180^{\circ} \mathrm{C}$, but at a higher temporature the beta hydroxy 1 reupe enter Inte the reaction with the formation of the three almontional polywer. Thu by keoping the temperature of reaction belom $180^{\circ} \mathrm{C}$ and taking camples on a test plate at intervals, it was possible to dotermine when all the alcohol had roaoted fron the appearanoe of the coolod realn.

Arter all the sulfonated alcohol had reacted, the temperature was rated to $200^{\circ} \mathrm{O}$ and the resin oooked unt1I the thickoning point we roached. At tines during the oourse of the roation sene of the sulfonated aloohol alatizled over with the wates berore 1 had reacted and this had to be subtracted fren the original anount of ulfonated aloohol to obtaln the actual anount incorporated in the resin.

Stirring ia in inortant factor in the production of a good realn. If the resin batoh was not atirred 
thoroughy throughout tho cooklng time, the culfonated aloohol atd not booeme theroughy mixed and conmequently ala not react oompletely cauming the oooled resin to have a elouty appearane cue to the unwated component. I teat cook was oondueted on two roulne of the camo composition and under the sane cooking condition, etirring one but not st1rIns the othor. At the oempletton of the $\min 1$ was round that the unagltated ratn had nore pronounced eloudy appearance than the stirred resin.

In opmparisen of the resins cooked from "Vol" and "Dreft" It was found that the product extracted rron "Val" soemed to reaot wore readily than that extracted from the "Dreft". Those rosins cooked frow the stralght ohaln sultonated aleohol extracted fron "Drert" and "Duponol" produced very dark colored resine wioh would be of limited application because of thetr coler. This more pronounced darkening of the realn oan be aceounted for by the greater inatability or those preduets than the surfonated aloohol rron the "Vol". For this reason the sulfonated aloohol trom "Vel" was used throughout this researoh.

The Initial resin was cooked uelng stelohlonetrio proportions of eljoerol and phthallo anhydride) that is, ratio of one mole of glyoerel to one and one-half mols of phthallo enhydride. All the resing were cooked using 46 grame (1 mol) of glyoerol and in each succeoding rosin part of the 
phthalie anhylaride was ubetituted for by the wulronated aloohol. Who mounte of mulfonated aloohol were ouloulated asuming the sulfonated aleohol to be entirely lauryl acla wulfate. This soumption is not ontirely acourate beoause it actunes on reactive ald sulfate group for every molocular welght of 266 wh1le the cotual product contalns two reactive groupe and a molooular relght of 4901 or one reactive group for every 245 und th of moleoular welght. Such an as sumption had to be made beoause the oompoltion of the vulfonated aloohol rrom "VeI" was not known at the outset of the researoh.

The eulfonated aloohol would be expected to have aclale properties beoause glycerol itgelf exhiblte aclale proparties due the the coumulation of the hydrexyl exoupe in the struoture. With these groupe replaced by acld sulfate groups, It dorinitely would exhiblt nold onaracteristica.

Tho oulfonated aleohol and phthalio anhydride both belng aclds, they would be expected to reat with glycerol In the following wanner.

Fathelis acta and girearols

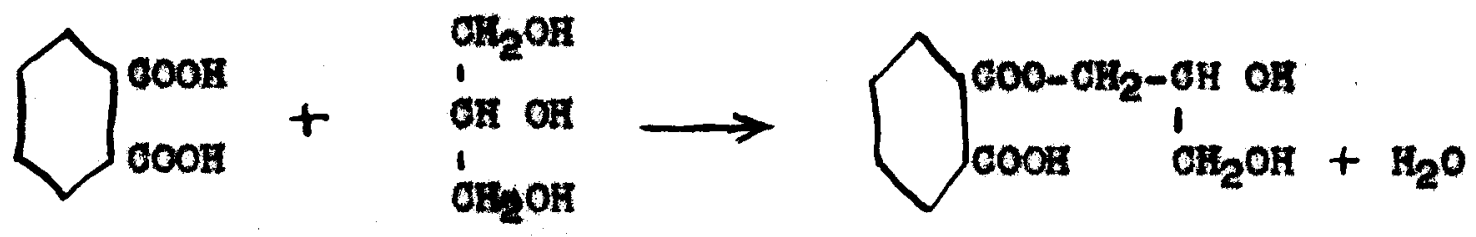


Stralght ohain sulfonated aloohol and glyoeroli

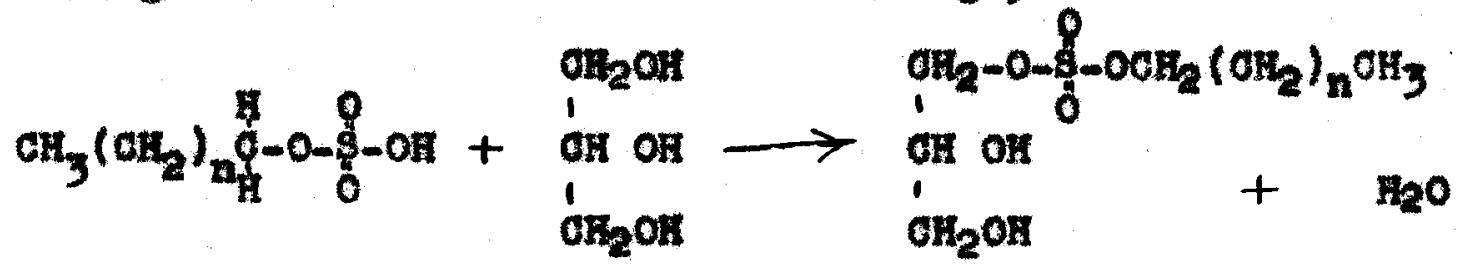

algeorel sulfongted aloohol and alyoorol:

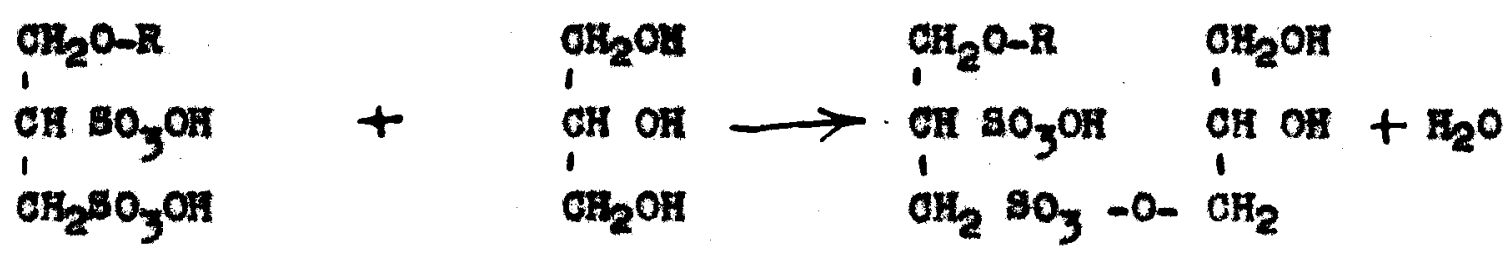

Since the phthalle acle and ulfonated aloohol both evolve water then thoy raeot with blyoerel, it was pousible to caloulate the theoretisal amount of vater whioh should be orelved in the rosetion. By colleoting the water condenced from the reaction, 16 was posible to follow the reaction and to moasure 1 ts extent.

A. a moens of oomparing the reactions, each resin waw oooked to the otifrening point and then ito esterifloation was acasured. X1enle and Furgusen (24) found that glyoorol and phthalle anhydride have only a moderate degree of eater1f1eation (75\% - 80\%) and was heat convortible oven when ro-

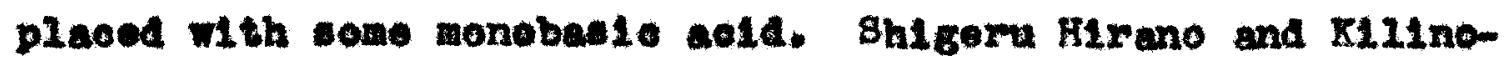
uthe Ohesh (27) found that stefoning ocourred at $70 \%$ esterification at all temperaturea when stolohlometrio proportions of glyoerol and phthalle anhyaride wore used. Arter 
32

utiffening oosurred very 11ttle water was ovolved, and furthor esterification eould be obtainod oxly by prolonged heating. 
DATA AND RESULTS 
ESTERTFICATIOA

In oach run the resins were oooked unt12 they reached the stiffening polat and the poroentage estorifioation was moabured by alviding the sotual water collected by the theoretioal water whioh thould be evelved. The proportion used in each run were 46 gram (t mol) of glyoerol and atolanionotrie proportions of phthalle anhrdride and the eulfonated aloohol. The rollowing tablo (rable I) shows tho offeot of the sulfonated aloohol medirioation on the esterifloation of the resin.

It ean be seon frex the aata that the sulfonated aleohol tended to inorease the peroentage estorifleation whith could be obtained in the resin, and this properts is shom graphleally on Figure 2. This was quite in secordanoo with the elndings of Hirano wa Ohashi (17) tho found that

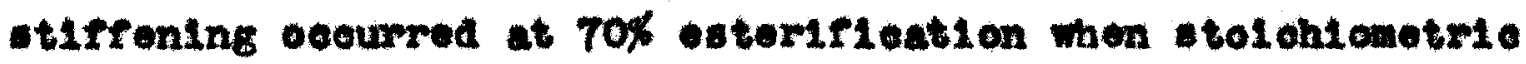
proportions of glyoerol $(1 \mathrm{~mol})$ and phthall anhydride ( 2.5 noli) wero used, and no ottfrening occurred below .88 mols of phthal10 anhyiride. Mnen the wulfonated deohal was ineorporated in the resin, the point of non-tiffening was ratsed 20 2.2 mole of phthalle anhydride as oompared to .88 nols whon juet the elyoerol an phthalle anhylride were used. 
TABLE I

Modirication va. Esterification

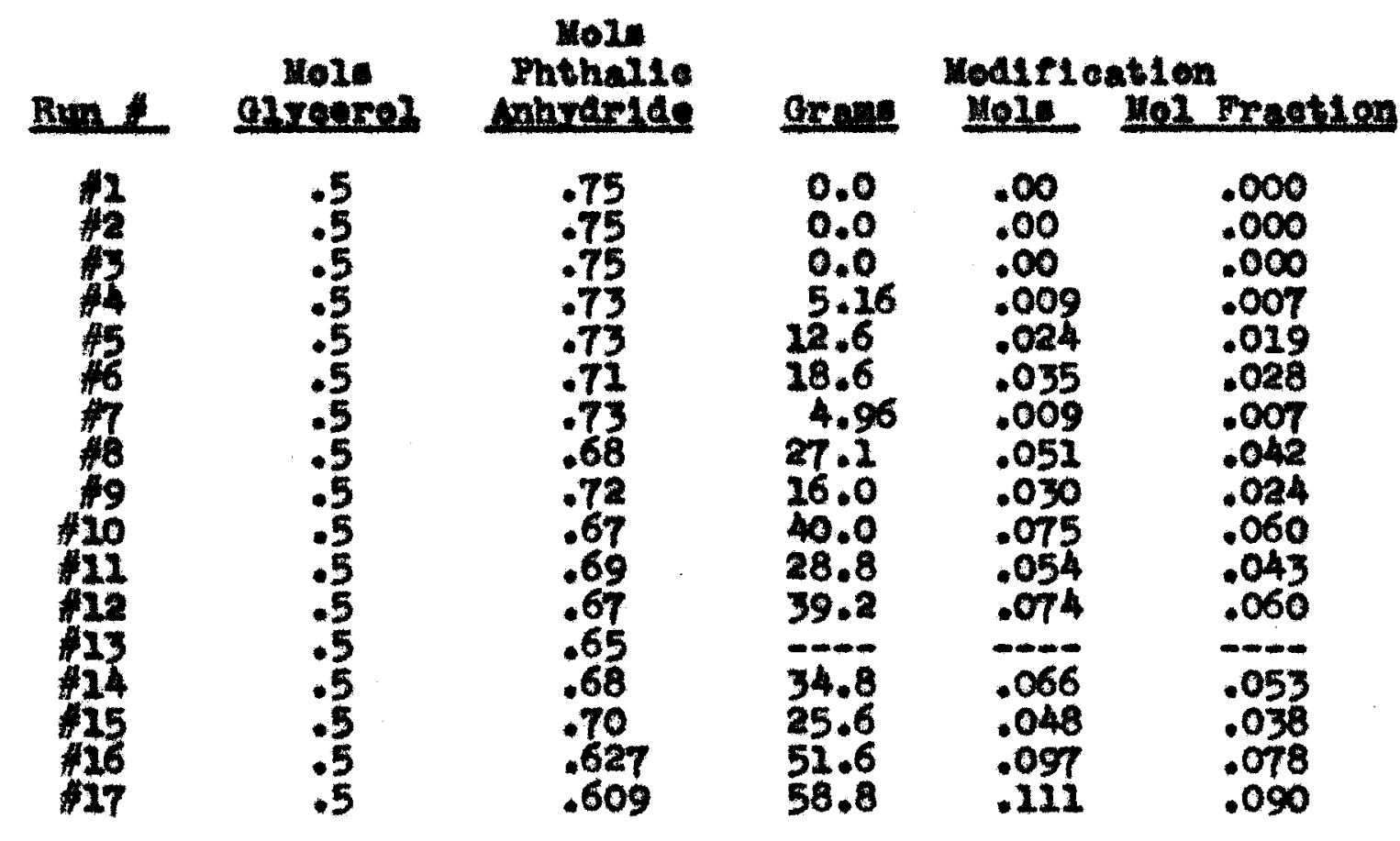

\begin{tabular}{|c|c|c|c|c|c|}
\hline Rum & $\begin{array}{c}\text { Cran } \\
\text { axresen }\end{array}$ & $\begin{array}{l}\text { Gran: } \\
\text { Phthalle } \\
\text { Anhronde }\end{array}$ & $\begin{array}{l}\text { Mod12 } \\
\text { Grenen }\end{array}$ & $\begin{array}{l}\text { aston } \\
\text { i. }\end{array}$ & $\begin{array}{c}\text { Peroent } \\
\text { Enteriflostion }\end{array}$ \\
\hline 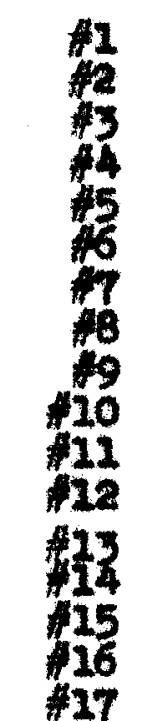 & $\begin{array}{l}46.0 \\
46.0 \\
46.0 \\
46.0 \\
46.0 \\
46.0 \\
46.0 \\
46.0 \\
46.0 \\
46.0 \\
46.0 \\
46.0 \\
46.0 \\
46.0 \\
46.0 \\
46.0 \\
46.0\end{array}$ & $\begin{array}{r}111.0 \\
112.0 \\
111.0 \\
108.0 \\
108.0 \\
105.0 \\
108.0 \\
101.0 \\
106.5 \\
99.0 \\
102.0 \\
99.0 \\
96.0 \\
101.0 \\
104.0 \\
93.0 \\
90.0\end{array}$ & $\begin{array}{l}0.0 \\
0.0 \\
0.0 \\
5.16 \\
12.6 \\
18.6 \\
4.96 \\
27.1 \\
16.0 \\
40.0 \\
28.8 \\
39.2 \\
=34.8 \\
25.6 \\
51.6 \\
58.8\end{array}$ & $\begin{array}{l}0.0 \\
0.0 \\
0.0 \\
3.22 \\
7.6 \\
10.9 \\
3.12 \\
15.6 \\
9.5 \\
21.6 \\
15.4 \\
21.2 \\
19.2 \\
19.1 \\
14.6 \\
27.1 \\
30.2\end{array}$ & $\begin{array}{c}55.6 \% \\
55.0 \\
56.1 \\
58.5 \\
68.9 \\
72.1 \\
60.7 \\
75.8 \\
63.8 \\
79.4 \\
52.2 \\
77.2 \\
-9 \\
\text { water. } \\
72.0 \\
77.1 \\
85.1 .\end{array}$ \\
\hline
\end{tabular}




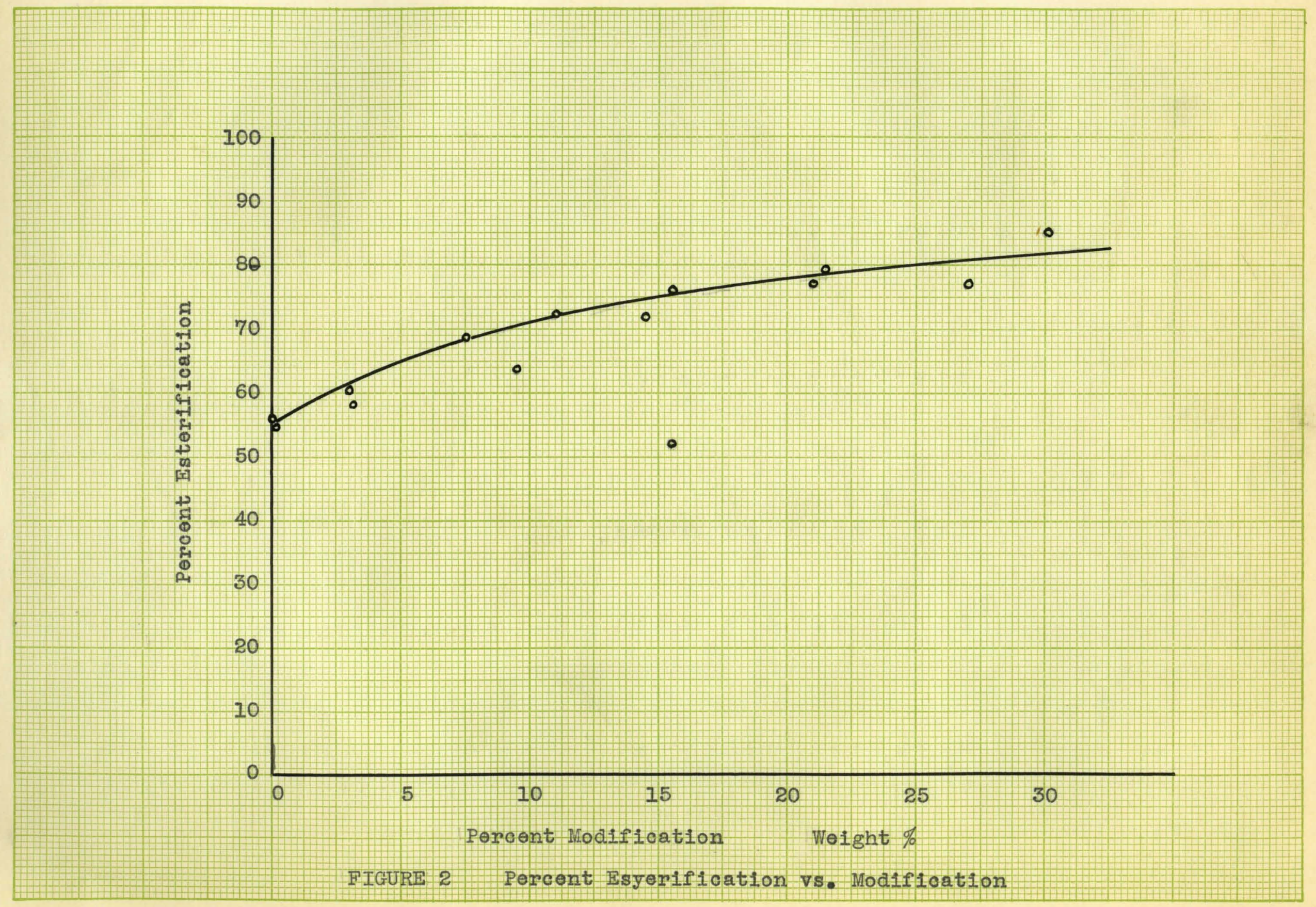


The questlon ar1ees wethor the components are reacting or just adnixing late the resin. Thothor the rooulting rodin is oaused by a reaction or just admixing io of ceoondary importanee to the raet that the wodifloation hall produed roaln uable in 2aoquer formulation, whl oh was the original goel of the researoh. Howevor, there are a number of oridonoes witoh indioate that there 14 a rosotion.

(2) In the original unodified rosin it was found that only about $60 \%$ enterifloation took place before the roIn et1ffonod and only 7.1 grume of wator wore orolved but in the case of the resin modifled with $30 \mathrm{wt}$. $\mathrm{x}$ of sulfonated woohol and uling the same smount of glyoorel, there were ovolred 22.7 erans of water oven though tho amount of phthale anydrite was roduced. The only place this Inoreased vater eould oone frow would be from the readion of the aulfonated aloohol and the glyeorel, or fron the lnereased esterIfloation of the groorel and phthalle anhydride, but had all the phthallo anhydride in the reain reaoted, there would have been only 21.0 grans of water erolred. A proof that all the phthal1e anhydride hod not reacted was show by the roaln having on aold number of 34, and this was a cood indioation that the wulonated aloohol reaoted.

(2) If the process were one of Anlxing, ane would uppose that if the renlne wore ground finely they would have the oharaoteriatio olly reeline of the sulfonated aloohol: 
but this is not the oase, for the otiffened realns wore hard and ground late a fine powdor.

There were alvo number of Paots that supported these conelusions.

(1) In many oases the sulfonated alcohol ocouplod an Inttial rolume approximately equal to the volume of glycerol and nelted phthalio anhydride. In rug $/ 17$ the resin mixture oocupled $100 \mathrm{ml}$. and the sulfonated aloohol $75 \mathrm{ml}$., which would made $1 t$ extromoly alfrioult to adm this rolume of Ilquid in such anell rolume of sollatfied renin. Resin hare been made Ineorporating as high as $90 \mathrm{ml}$. of bulfonated alcohel in the sane rolume of resin alxture.

(2) It was proviouly discused that during the oooking of the realn the appearance of the realn alxture changed rrom oloudy to olear as the cooktng proceeded and rematned olear at the complotion of the reaction. The oloudy appearance at the start of the reaction was accountable to the Inilsolb111ty of the resin componente and the sulfonated alohol. The disappearance of this eloudy color was accounted for by the reaption of the uulfonated aloohol, or by the alsatbility of the sulfonated aloohol and the finishod rosin.

(3) Thon a saple of a highly modified resin was asemelved in a solvent and the solvent ovaporated rery slowly from 1t, the original rosin was recovered indicating a more 
Intinate bond than just admixing.

Coomina TIR

Broh Inorease in modifieation of the pure alky Wth the sulfonated aloohel had a tondenoy to inoreace the time of cooking. It was found that it took only 120 minutes for the pure eikgd to reach the thlokening point at $200^{\circ} \mathrm{C}$. whoreas the resin with 30,2 wt. peroent of the sulfonated alcohol inoorporated in 1 did not thioken and "set" in the flask mon arter heating approximately four hours at the sane temperature.

COLOR

Wren oooked in an inomt atworphore, the pure alkyd reein has alear, water-white, glest-11ke oppearanoef but as the resin 18 modified the eolor becomes progreadivly darker until the rouin in run $\$ 17$ (30.2 th. $\%$ modification) is a bromith ooler but at1il retainu its elear appearance.

KLRDMDAS

The haxdiness of the rosins ohenge from a very hard, brittle, pure alkyd resin to a wort, sugh, and r2exible roaln when modified with 60 gram $(30.2 \mathrm{mt} . \$)$ of the surfonated aloohol. Then 80 grans (38.1 mt. \$) wore inoorporated 1nto the rosin, it was found that a mubery rosin resulted which would not harden but rotalned 1 to atloky feeling. Bocause of 1ti very tough and rubbery properties, it may have 
ane appleatlon in the ahedres rield.

It was epparont that the awronated eloohol aoted as a platifoter in the alkg roetn, and this property was rery important if the resine were to have any applioablilty in proteotive vouting applications. 
SPRCITIO GRAVTTX

15 wat expooted, the specifio gravity of the resine decreased as they wore further modified because the unlfonated aloohol wa a Ilquid with speolflo gravity 200 s then unity. and rotarded the foration of large, oomplox, h1gh wolecular welght molecules.

The apesifle gravities of the rosine wore deterained by the water displeooment method, by moasuring the water displaed by a know wolght of realn. The data are listod bolow and are thom graphteally on Mgare 3.

\section{TARE II}

Speolrte Granty Vo. Modifleation

\begin{tabular}{|c|c|c|c|c|c|}
\hline Rum 1 & \multicolumn{2}{|c|}{$\begin{array}{l}\text { Modif1eation } \\
\text { grome Fi. } 4\end{array}$} & $\begin{array}{l}8 \text { axple } \\
\text { of pesin }\end{array}$ & 96. water & Bp. Ge \\
\hline 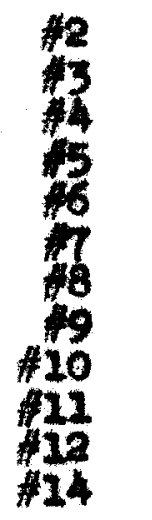 & $\begin{array}{l}0.0 \\
0.0 \\
5.16 \\
12.6 \\
18.6 \\
4.96 \\
27.1 \\
16.0 \\
40.2 \\
28.8 \\
39.2 \\
34.8\end{array}$ & $\begin{array}{c}0.0 \\
0.0 \\
3.22 \\
7.6 \\
10.9 \\
3.12 \\
15.6 \\
9.5 \\
21.6 \\
15.4 \\
21.2 \\
19.1\end{array}$ & $\begin{array}{r}9.829 \\
15.027 \\
12.329 \\
12.208 \\
12.589 \\
12.619 \\
13.320 \\
8.604 \\
9.034 \\
10.659 \\
5.836 \\
11.932\end{array}$ & $\begin{array}{r}7.40 \\
11.10 \\
9.31 \\
9.15 \\
9.80 \\
9.51 \\
10.39 \\
6.50 \\
8.30 \\
8.50 \\
4.90 \\
9.28\end{array}$ & $\begin{array}{l}1.330 \\
1.356 \\
1.332 \\
1.338 \\
1.299 \\
1.329 \\
1.280 \\
1.325 \\
1.185 \\
1.276 \\
1.295 \\
1.275\end{array}$ \\
\hline $\begin{array}{l}\$ 15 \\
716 \\
\$ 17\end{array}$ & $\begin{array}{l}25.6 \\
51.6 \\
58.8\end{array}$ & $\begin{array}{l}14.6 \\
27.2 \\
30.2\end{array}$ & $\begin{array}{l}13.795 \\
14.026 \\
13.399\end{array}$ & $\begin{array}{l}10.61 \\
11.60 \\
11.42\end{array}$ & $\begin{array}{l}1.301 \\
1.210 \\
1.172\end{array}$ \\
\hline
\end{tabular}




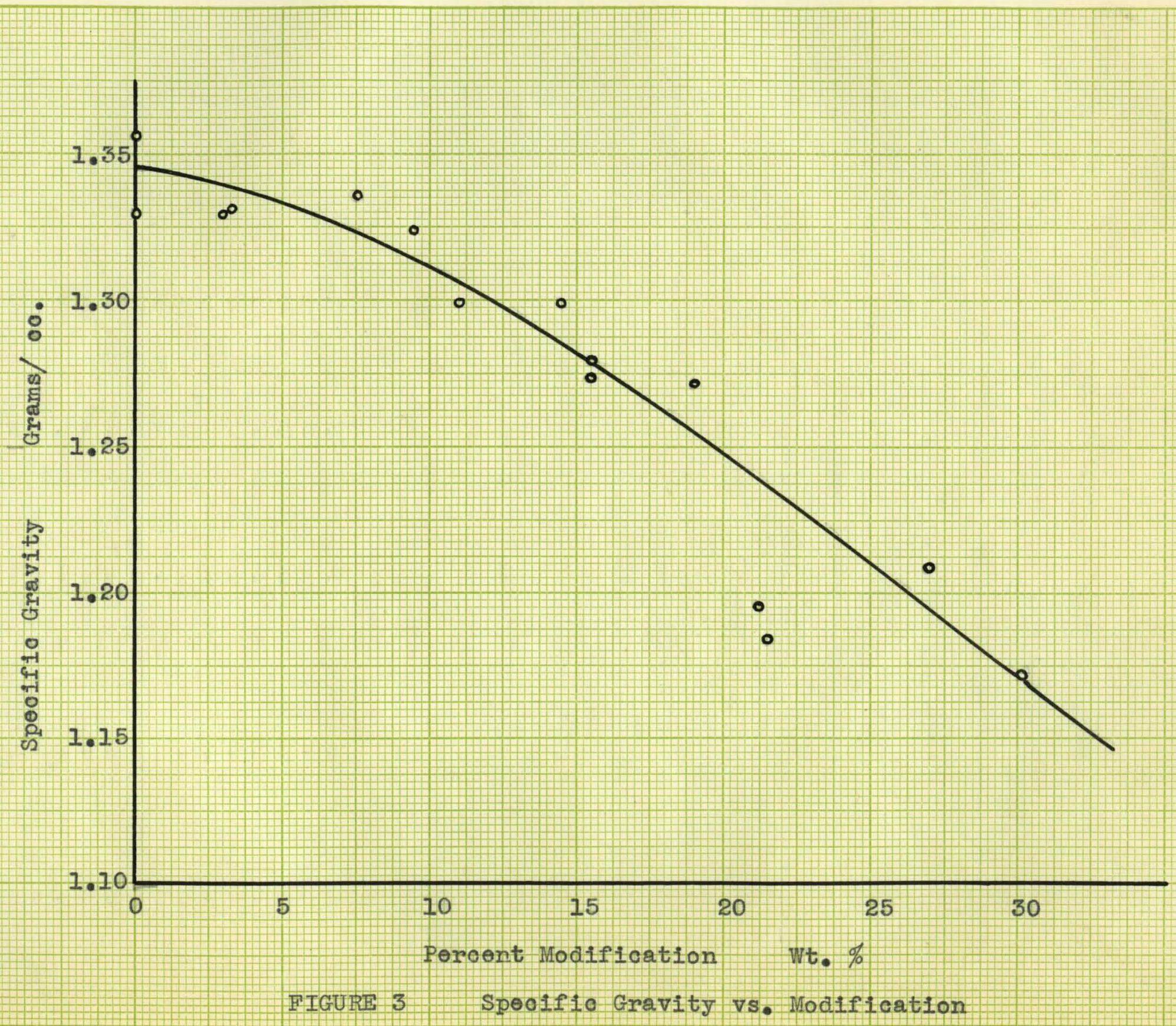


LOTD NUTBRa

At the atart of a rosin cook a derinite amount of add (phthalle anhydride) and the other constituente of the resin wore placed in the reaction Mank, and whese reacted the anount of unpesoted cold deoreased becaume the oarboxyl groupe of the phthalle acid wore being eaterified by the hydroxil 2 groups of the elyoeral. During the oooking of the roaln the mase ustually gelled or reached the infunible state before all the carbexyl grouge were reacted, leaving the reIn wth a cortaln anount of Iree acla. Frerlous roforencen have shom this to be about $60 \%$ - $70 \%$ reastion.

The acla number of a reain 10 a mosure of the froe aeldity in the resin and is defined as the number of mililgrans of potaselum hydroxide nocessary to neutralise the froe acid in a one gran sample of the resin. It 10 desirable to have as 10 in acld number as posulble in the realn, for the greater the free acld the more rulnerable is the reain to ceterioration.

The procedure uned in determining the sald ralues wat to wetgh a kmown welght of realn (approx. one gran) inte - $500 \mathrm{ml}$. orlenmeyer rlask! this was treated with $25 \mathrm{ml}$. of acetone and allowed to stand (preforable overnight) unt11 all the froe we1d was alsoolved. The wold solution was taken up In 250 m. of Aistilled water and the solution heated to romove most of the acotone. This solution was titrated with a 


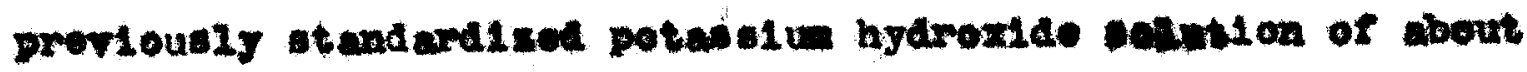
five unite of sold nuber por eublo contineter, using phenolphthaloin as the Indioater and titrating to the firet plnk

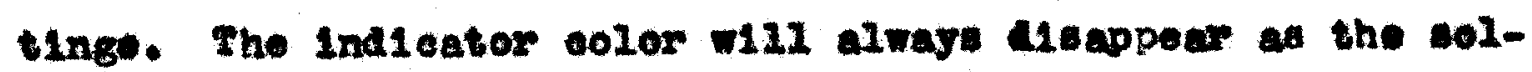
utlon stand sinee on exoess of base 111 always sepenify the resin in the botten of the $\mathrm{nask}$ unt1I thic rosin entirely a1sappoars. Frow the weight of canple and the oublo cont1wetere of base used, the aela numbera of the rosins wore oeloulated. Three samples wore men on each rosin and the arorage taken. The trond of the acld numbers are as tollow, and are hown eraphioaliy on Pigure 4.

\section{TABLE III}

\section{deld Value vi. Hodification}

Prmat

Medifieation

Crome Ites

Anst volue

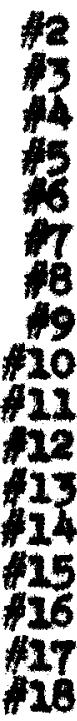

0.0
0.0
5.16
22.6
18.6
4.96
27.1
16.0
40.2
28.8
39.2
34.8
25.6
51.5
58.8
80.0

0.0

0.0

3.22

7.6

10.9

3.12

15.6

9.5

21.6

15.4

21.2

160.0

$\mathbf{2 7 5 . 0}$

125.7

118.0

114.0

109.4

67.0

82.7

56.0

32.2

75.8

29.1

14.6

27.1

30.2

38.1

55.9

41.5

34.0

34.0 


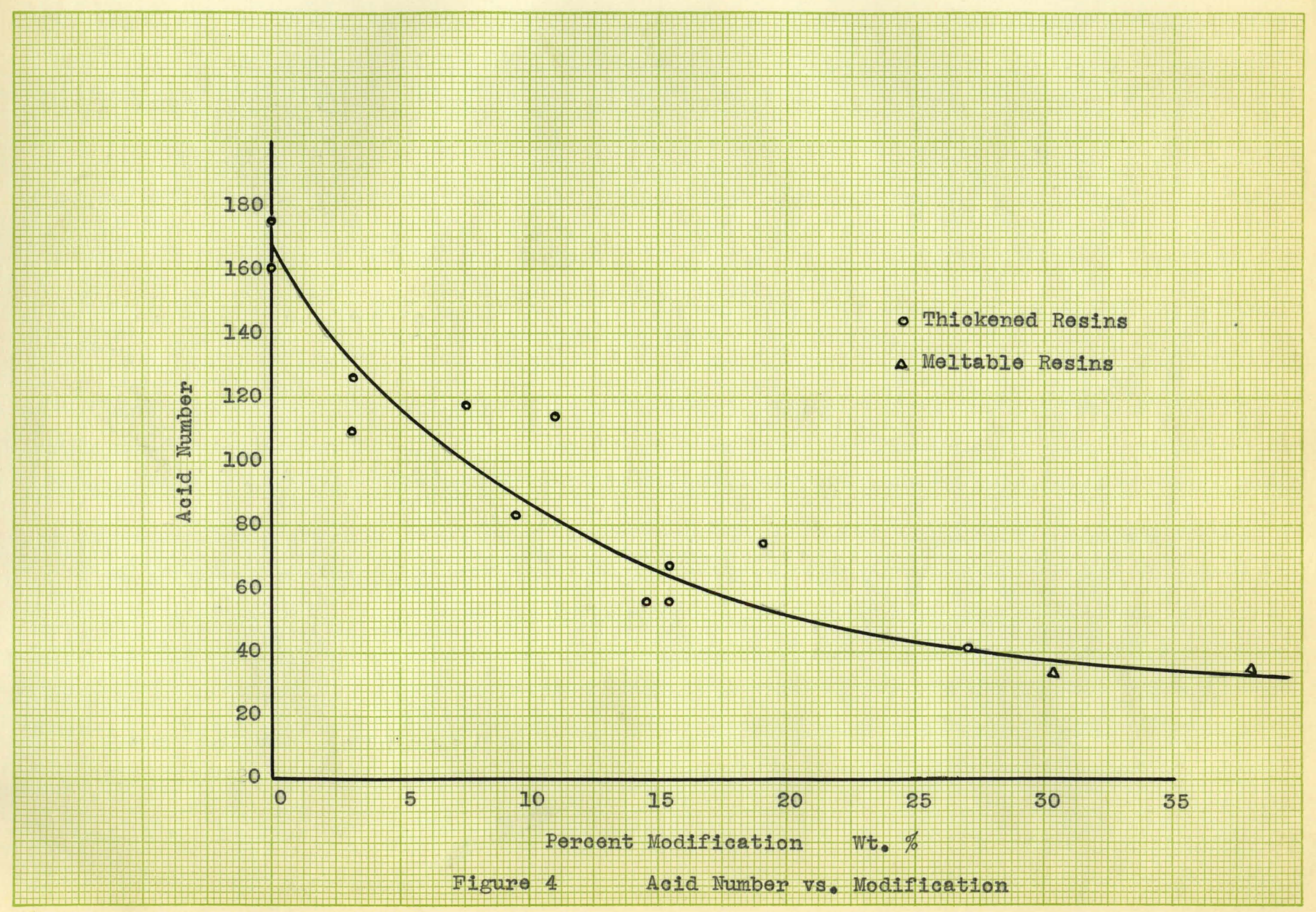


It cen be seen from the date that the acid number cocreased as the resin was modifled: This was to be expected 1neo it has been ceen that the esterification inoreased as the realns were modifled, whloh neceseltated more of the phthalle ankydride to reat. The offect of the sulfonated wiohol was protumably to retard the gelling of the realn allowing more of the phthallo anhyaride to reat.

It must be resembered when oonsldering the cold numbers of these realns that oach rosin was oooked using otelohtometrio proportions of material and in order to obtaln an cold number of zero, the reaction would have to go to oomplet10n. The object was not to obtain at 10w an acld number as possible in oach resin, but rather to find how the acid nuber ohanged as the realn wan modified.

Lower aota number oould be obtalned in eaoh of the roeins in a number of waye. First. If an excess of glyeerol wore used over the theoretieal anount, there would be more hydroxy 1 groupe for the oarboxyl groupe of the phthalle anhydmde to react with, and oonsequently there would be less Proe phthalis anhydride in the rosin. Second, in indurtry, before the resin is finimhen cooklng, a strean of inert gas 1. bubbled vigorousig through the roeln whioh oarries the unreacted phthallo anhydride with it and sublines it on a oold wall outs1de of the resotion ressel. In this manner mont of the unreacted phthallo anhydride was removed, leaving a resin 
wth a low acid number. This effeot was not apparent in th1s rosedreh because the veloolty of the oarbon diextle gas wa too $20 \mathrm{w}$ to remee the phthall anhydride rapor frow the r.ook.

The theoreticel relationahlp between molecular weight and acld number representing varlous stages in the - sterifloation of phthallo anhydride and glyoerel was given by Ellis (14) and is shom belon where $P$ ropresente phthallo unhydride, and 6 ropreaente glyoerol. A terminal $P$ iaplied the prosence of a carboxyl group, and a terminal a reprosented a Alnyaroxy group.

\section{TABR $\mathbf{X Y}$}

Molooulas Wolght re. Aold Number

\begin{tabular}{|c|c|c|}
\hline Zoxmin & $\begin{array}{l}\text { noleoular } \\
\text { bletht } \\
\end{array}$ & $\begin{array}{c}\text { Aold } \\
\text { Lumber }\end{array}$ \\
\hline 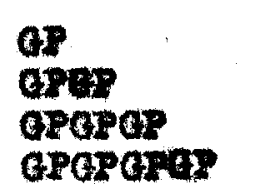 & $\begin{array}{l}240 \\
462 \\
684 \\
906\end{array}$ & $\begin{array}{r}233 \\
121 \\
82 \\
62\end{array}$ \\
\hline $\begin{array}{l}\text { PaP } \\
\text { PAPaP } \\
\text { PAPAPGP } \\
\text { PGPAPGPOP }\end{array}$ & $\begin{array}{r}388 \\
616 \\
832 \\
2054\end{array}$ & $\begin{array}{l}289 \\
184 \\
135 \\
106\end{array}$ \\
\hline
\end{tabular}


SOLUBITIXY

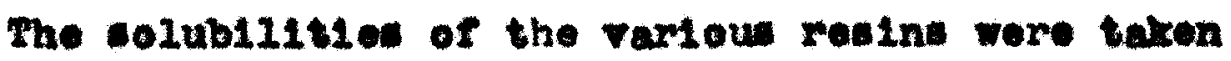
ulng averal alferent colvente to chom thelr trend. Sinoe the resing were oooked to the stifrening polnt. the selu-

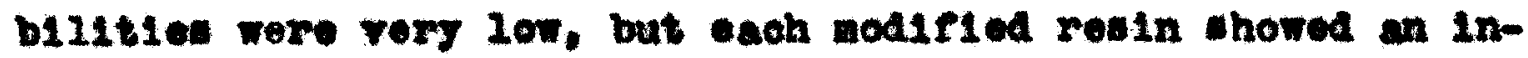

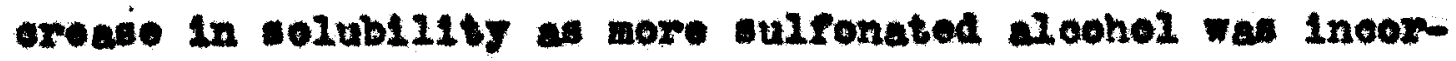
poitated.

The colubilition were deternined by merluxing an excens of restn for one helf hour in appoximately $150 \mathrm{~m}$. of solvont, arter wateh time the colution was allowed to

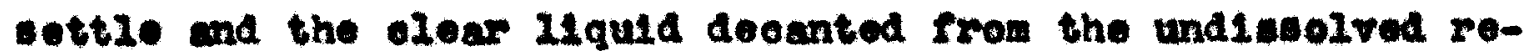
4n. The olear Ilquid was placed in a prorlousiy wolghed Mas and the solvent alet1lied rom the realn. Artor arying the rask in an electrie oren to ronove the last trane of nelvems. It wa wolghed ogain and the welght of realn in the know emount of colvent was determined (25). A12 the colublistien were eanverted to grane of realn alssolved in one 11ter of solvent, and they are plotted as woh on Flgure 5.

In al solvate there was an inomese in colviolit ty oron though the rogotion had prooveded to a greater anount of osterleleatlon, showling that the culfonated aloohol had increased the selubl11ty. After a1xty grans (30.2 we. \%) ware Inoorporated, the redin no longer resched the stifrening point and there was a maxed inoresse in the colub121ty. Frow 
obervatioa of the maltefonod rouin it has boen noted that those resins having the greatest modification discolved more reatly then those of lower modifieation. The solublity data are tabulated bolon and are expressed sraphieally on Proure 5.

\author{
TABLE 7
}

Solubility ve. Modrlicatiea

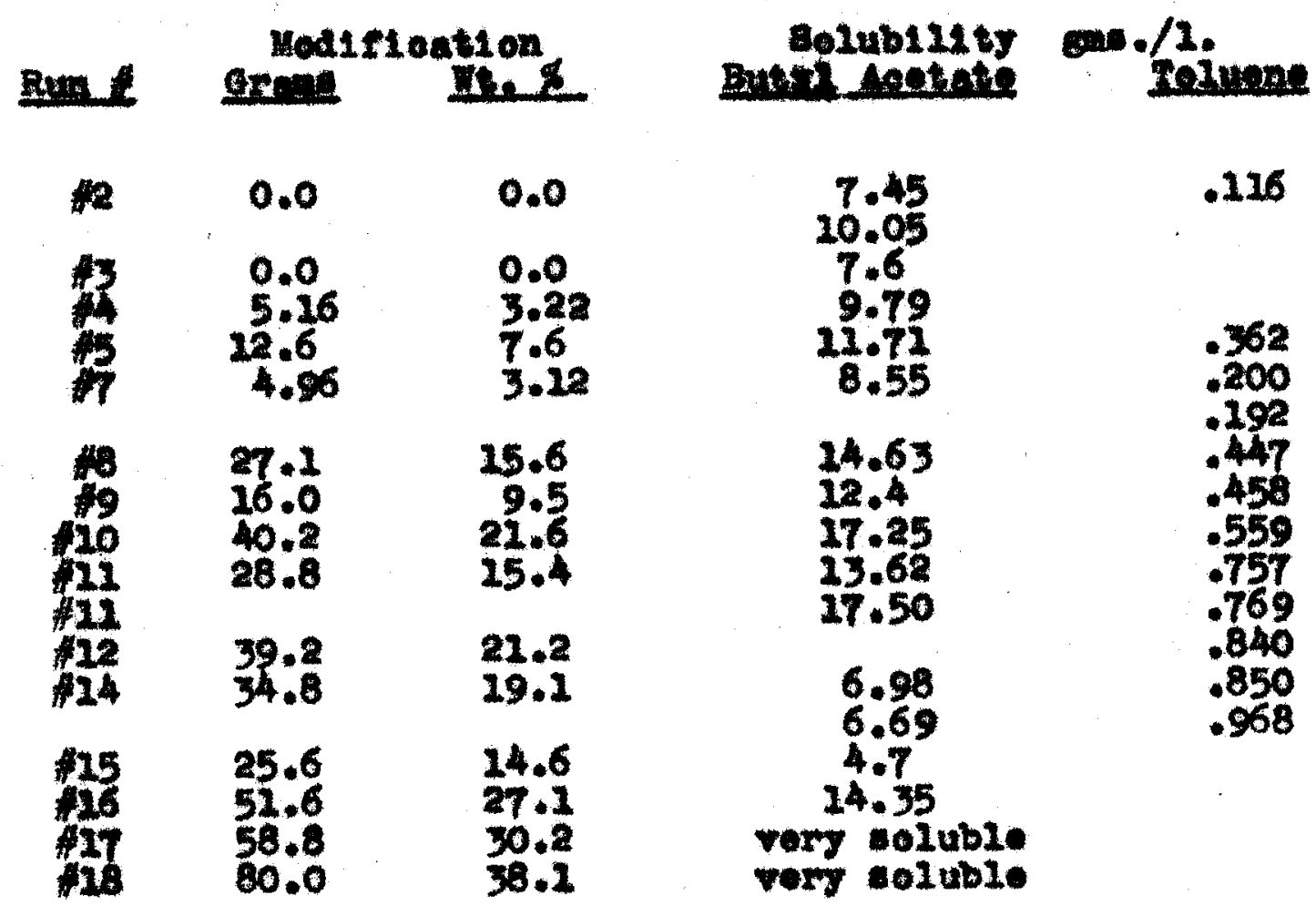

A a result of cooking the resins to the stiffoning polnt, It was apparent that the colubllikles were very low. In most cases they were so mall that it was difficult to obtaln very acourate data, but from the date gathered 16 wes show that the colubilities inoreaced as the allod resin 


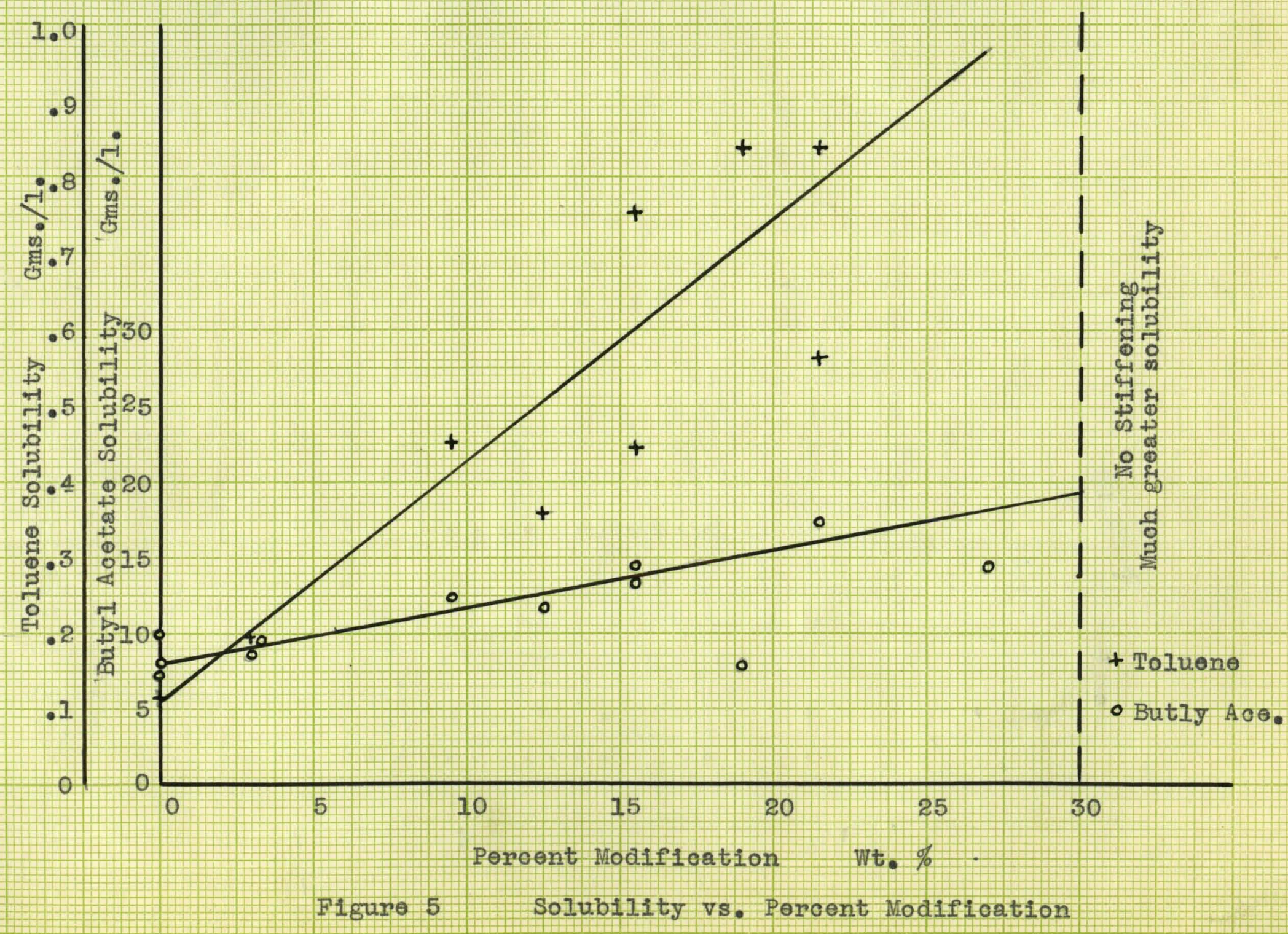


vere adifled. However the data dia chor the insoluble and the infusible form of the atage o roskn. They alse showed that buty acotate was auoh better colront for the alkyd realns then the ring selvent toluene.

SInos the prentou rosin were cooked to the thickening polat, It wa imposatble to digeolve then in any solvent to areat onough cogree to oadt a film grom then. Botare the rosing eould be applite in ravalshos and laequers, ponopla hal to be wade by taktng tod drope of the realn onto - clas. plate in order to determine whon the correct vieeenty had been reached, and atopping the reaction just before it oane into the Infusible and incoluble state. In thie namner on asta number as 20 as posulble was obtalnod wthout the restn beooning infusible and involuble.

The reoooked resine contalnod the following modifloatloai no unfonated aloohol, 21 grams, 40 gram, 58.8 gram, and 80 gran of the sulfonated aloohol all besed on one halr mol of elyeerol and three fourth wol of phthallo anhydride.

COUPATIBILITY

An Important factor in the produotion of lacquer: wae the question of the oumpatiblitty of the resin. with Altrecelluzose, ethyl collulose, or other oellulose laoquer bases. Compat1bilition were a seasure of the anount of rosin 
when eould be minod with the oolluzoes donlvitive without produaling a elovey lequar.

Compatibilition wore tested by preparing a $50 \%$ walution of rouin in a colvent, and adding this to a $6 \%-10 \%$ solution of nitroouliulose or collulios derivitive in the sane colvont unt11 the solution showed a sight hase due to the Inocapatsbi24ts. Buty2 acetate wa uged as the solvent because all the roblne atasolved in 18 sere roadily then in any other colvent. A mixture of gof toluene and $10 \%$ othy eloobol 1s goneraliy used for oompatiblitty rums, but all the resins were not soluble enough in this mixture to permit its use.

Arter ow mall adition of resin solution to the

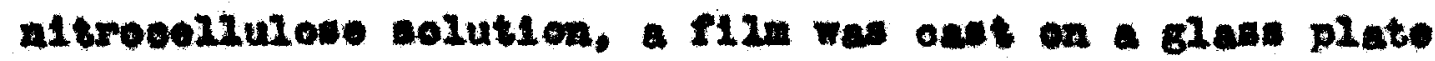
and allowed to dry. Two offeots of resin inoompatibility wore reoognised in cetermining the compatibility Ifmits with the

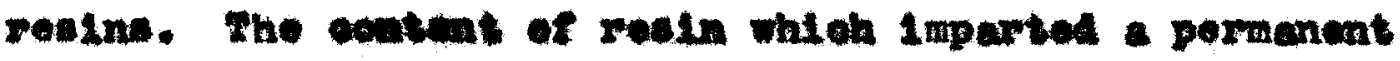
alight hase to the film was noted as the $21 \mathrm{nit}$ of hase rreo ecapaliblilty. Sinee many of the hasy filas are apporently homogmaow and orten possessed a high gloss, a socond oompatibility limit wa determined the resin oontent at wioh the t11 began to lose glow. Many realns woule be sat1sfactery in plementod lequer at coneontration connider- ? ably higher than the hase troe 11 int required by olear r12ms. 
The coapatiblilties were expressed st the peroentage of resin as compared to the welght of nitroosilulose or ethyl oollulose. This moan that a 50\% compatiblilty ladieated thut 5 gram of resin were compatible w1th 10 grane of nitroed12ulone In the 1noquer. The results of the coupat1billty tests are shown on Table VI.

The results of the compatiblilty teste showed the inorease in compatiblilty of the resine with both ethyl oel-

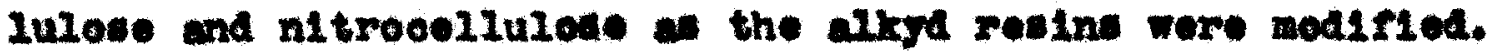
It aleo showed arkod affroronoe in oompatibility in the two celluloee dorivitiven, It belng much more compatible wth nitreodiulose than the othyl oellulose.

The fact that nore than an oqual anount of $30.2 \mathrm{wt}$. peroent modifled rouln was compatible with a defint to wolght of nitrocelluiose suggested the posalbie we of the resin in nitrocellulose laequers. 
TABLE VI

Compatibility ve. Moditioation

Reuin Solutions

Lo4180mion

0.0
21.0
58.8

Totrotenters

0.0

21.0

58.8

0.0

21.0

58.8
Qne. Rases

14.102

15.965

9.72 se Bolrent Geden (ear)

21.0
23.2
13.5

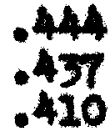

410

\section{Compat1b1218y Tose}

Gns. Derly, In 10\% solution

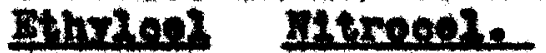

6.100

6.053

6.005
Liquid Here Limit 20

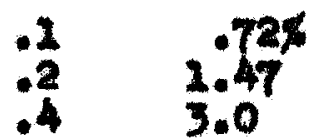

6.472

5.335

8. 559
.2

5.3
$.3 .68 \%$

Lodelontion
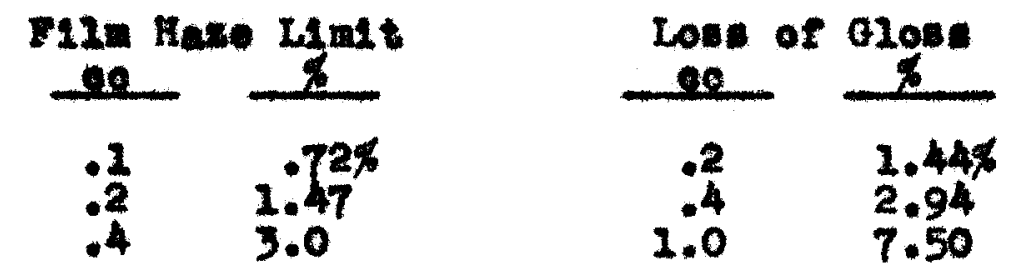

0.0
21.0

58.8

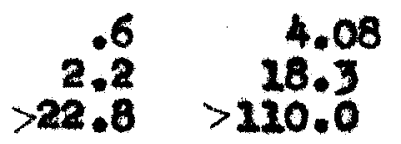

- Very s11ght 
APEIOATIONS 
I.Neguras

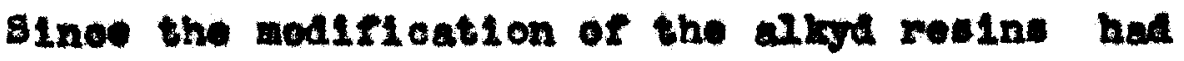

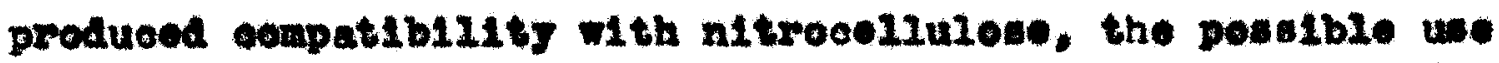

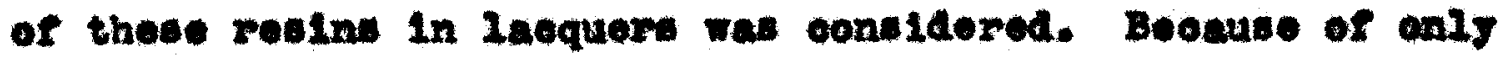

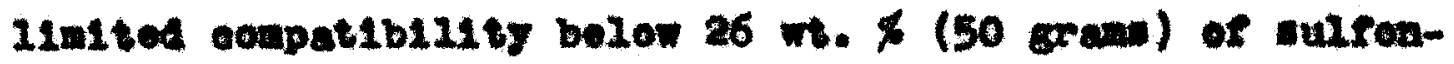
ated loobel, only those resine bove this nodiflostion wore applied in the laequex woxt.

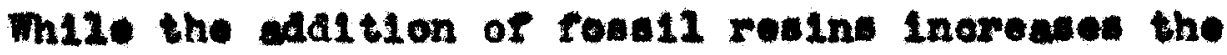

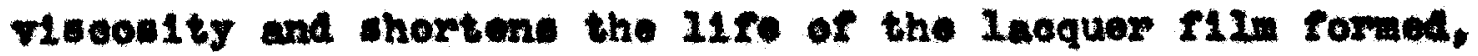

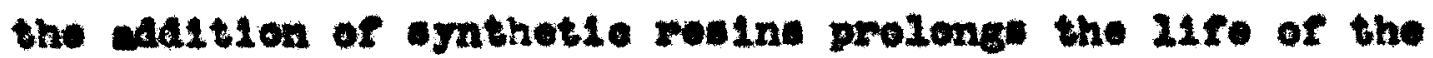

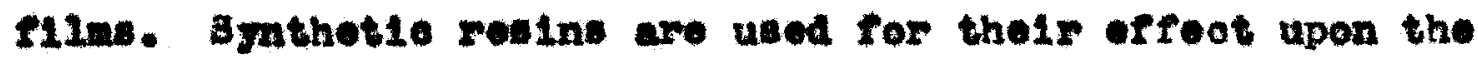

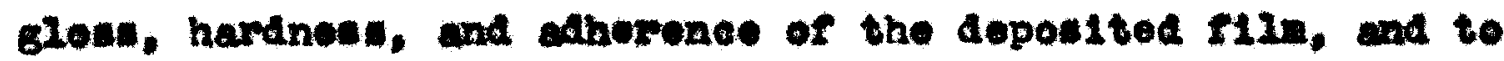
Indrece the collas content of the elution without mater111y inereating the riseostty.

2here are two trpes of agathetie resing used in lacquer formulationet hard resing and plastlo roetne. Hard

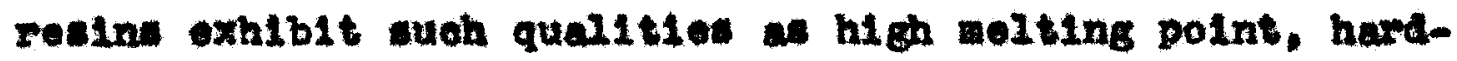
nots. rapla release of solvent. Ior visoosity in colution.

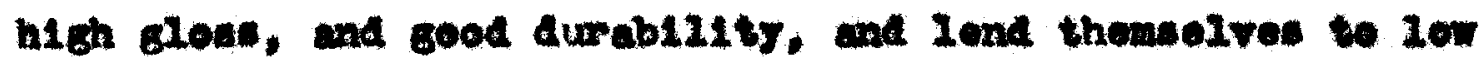
ratie introdued to the nttroosiulose oontent. The paquire

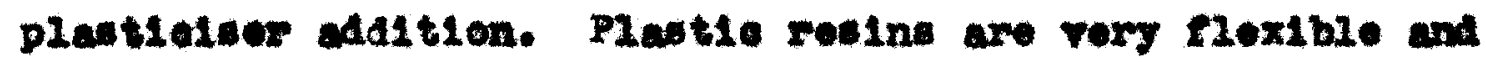
pornt the use of a relatively high rablo or rosin to nitroollulose. They do not at at plastolem howorer, and a plastioles nust bo aded. All the modified resine used in the following laqquex formulation in this thesis rould be 


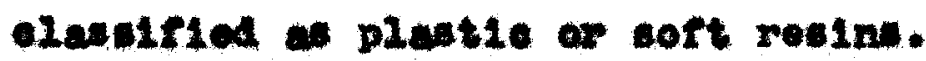

Realns perfora the function of chestion to an applied surface, Inorease the lustre, permit rubbing of the

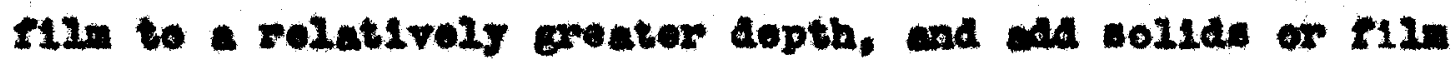
buslating propertiel.

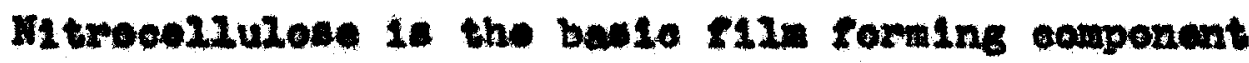
and Iaproves the arying time, hariness, and watep resistance of the reaulting Iaequar.

Plastlelwers Inerease the elongation of the riln. PLetloteme alce inoreace the now of the lagquer just before 1t wot to produce a level $\mathrm{rln}$ and provent blushlne. Ther play an important part in fuing the resin and nitroceliulowe

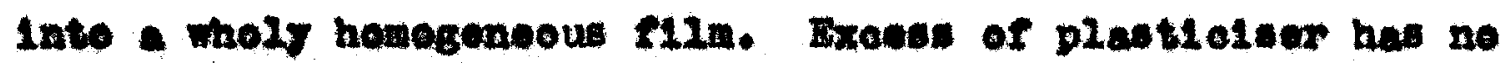
bearing on blos:, and there 16 an optinun plastloler content bejond whioh ne inorease in aherenos, tonslle strength, or glose of the 211. ocours. It w111 be noted that each ingredient Imparte to the lacquer oertain specifle propertion peoullar to that ingrealient, and it is elmost hopelese to expot to obtaln 21 the andrable proportion in one laoquer It the sane san matertall.

\section{Leqquer. nore made in rariou formulations using} the modifled rosin, tocond nltrocellulose, and castor oll as the plastielsor. Butyl acotate was used w the solvent throughout the roxk, and all the viscosities were adintalned 


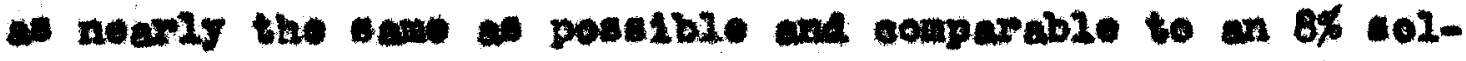
utlen of sevond nitroosliulose in buty 1 sootate. Those Inequere were wubjeoted to rarlou teste to deternine the ofroct of the resind the rosulting film.

Mhorenew (93)

Film of eabh laoquer wore cant on in plates using - .008 Ineh film deetor blace and allowed to ery oremight. Whoh plate we oloaned thoroughly uaing toluone and a doan ras before the lacquer was oast upon 1t. The aried lagquor we ariwerossed inte $1 / 16$ inoh wquares with a rasor blade. If the lacquer rlaked or peeled in outting. the adherenos vas vory poox. If 1 t renalned on the penol but coule be remorad canly ath the thub nald, It we rated poor. If a

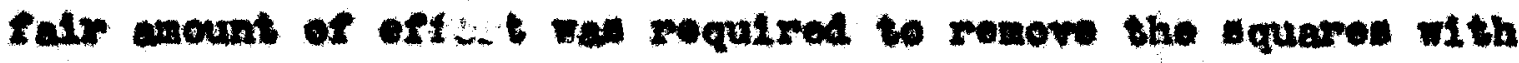
the thub nall, the adhorenoe was falx. If a knito blede was required, the odherence was rated as cood.

The ohomi eal struature of the plastlolecr has a certnite bearins upen the ahoronew. In general phosphates nure a beter ahorones than do other trpos of plastiofsors. Mhorene of a laoquer to aleo groatly arfocted by the wumraoe to whioh It 28 applied. $\triangle$ lacquer that il ahoront to

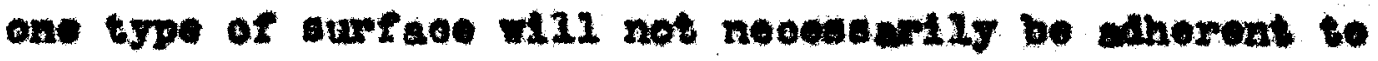
another. 
Brittzeness: (33)

A moasure of the brittlenesd of the lacquers was made by bending the previousiy propared tin plates at aharp angle and rating the fling as pased or falled according to Whethor the r1In oracked or not. The brittieness of a lacquer 1s inoreased with the grester wount of resin in the formulation, and it is the function of the plantielsor to roduoe this tondenoy.

Peno11 Hardneasa: (33)

As a moans of determining their rolative hardnoss, rila of each lacquer wore calt on cloaned and driod tin pmele and llowed to dry orernight. The laoquers rere tested by aratohing the films with a numbr of ponolis of rarying hardines (2B to $8 \mathrm{f})$. By writing on each film using the ware writing prossure and using suocessively penolis with harder load (3B, 2B, B, HB, F, H, 2H, 3H, 4H, 5H, 6H, $7 \mathrm{H}, 8 \mathrm{H})$, one could observe whet hardneas of lead was necesaary to soratoh the $111 \mathrm{~m}$. The hardness recorded was the coftent lead whioh would out the filn.

Th1. test gives only a measure of the relative hardnose of the films, and is dependent upon the person doing the teating. It was generally oonsidered that a hardness of 4H 1s a good file hardness, and all lacquers harder than $4 \mathrm{H}$ have been rated a passing. 


\section{Cola Ohook rent: (33)}

Lacquar f12" are genorally eubjeoted to the cold cheol teat to loteralne tholr durablitty and Rexibility. Filne wore sast on $4 \times 6$ inoh steel plates whioh hed proFeunly boen woll cleaned with solums. The plates wore then bubjocted to altemate poried of one how at $150^{\circ} \mathrm{T}$ and one hour at $-5 \%$, oare belne taken that they wore transferrad ax rapidy as posable trow the hleh to low temporaturos, a portich of one how at each temporature, or two houre in all,

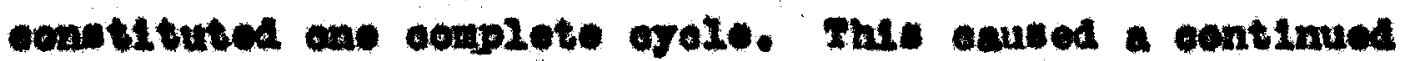

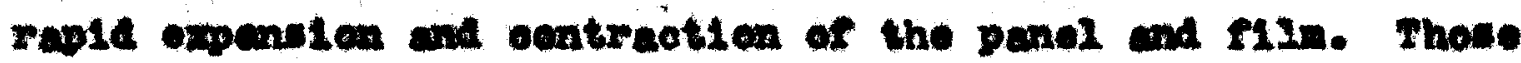

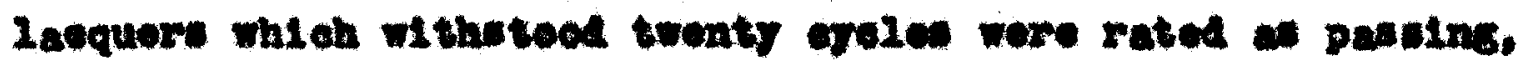
and those that doreloped ehooking during that ported wore consteored rallures.

Twe formulatiens of lacquere wore node, one usling the realn contalning $30.2 \mathrm{wt}$ \% (58.8 crase) of the wuronated leohol. and the othor centaining 38.1 wt. $\%$ (80 grass) of the culfonated aloobol. Inequors made mon the 21.1 wt. 4 (40 grans) medifica rosin oxhibited inoompatibility haso,

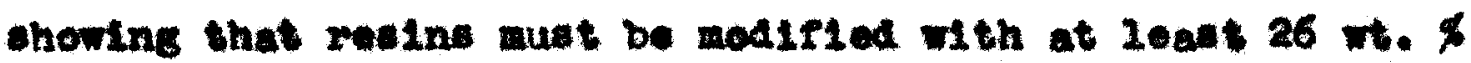
of aulenated aloohol to be userul in laoquers. The tablod following Ilst the lequer data, and they are alse procented graphioally on the trilinat Figures 7 and 8, roupoot1rely. Leoquere noed not fulfill all the requiremente for 
any apeotel propose, and the regten mooting any upeotitio

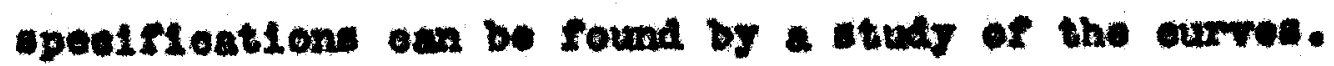


Lacquer Properties rs. Iacquer Compostion

30.2 nt. $\$$ Resin

Laoquer

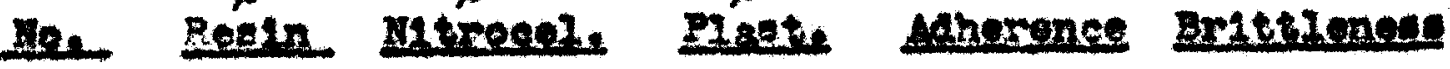

\begin{tabular}{|c|c|c|c|c|}
\hline 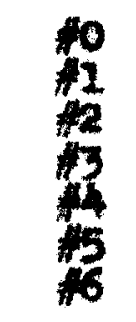 & $\begin{array}{r}0.0 \\
29.4 \\
39.0 \\
22.0 \\
44.2 \\
52.5 \\
100.0\end{array}$ & $\begin{array}{r}100.0 \\
70.6 \\
61.0 \\
77.8 \\
55.8 \\
47.5 \\
0.0\end{array}$ & $\begin{array}{l}0.0 \\
0.0 \\
0.0 \\
0.0 \\
0.0 \\
0.0 \\
0.0\end{array}$ & $\begin{array}{l}\text { good } \\
\text { ralr } \\
\text { poor } \\
\text { good } \\
\text { poor } \\
\text { poor } \\
\text { falf }\end{array}$ \\
\hline $\begin{array}{l}c 10 \\
620 \\
630 \\
030 \\
040 \\
050\end{array}$ & $\begin{array}{l}0.0 \\
0.0 \\
0.0 \\
0.0 \\
0.0\end{array}$ & $\begin{array}{l}90.0 \\
80.0 \\
70.0 \\
60.0 \\
50.0\end{array}$ & $\begin{array}{l}10.0 \\
20.0 \\
30.0 \\
40.0 \\
50.0\end{array}$ & $\begin{array}{l}\text { good } \\
\text { good } \\
\text { good } \\
\text { falr } \\
\text { folr }\end{array}$ \\
\hline$H$ & 35.0 & 35.0 & 30.0 & fatr \\
\hline
\end{tabular}

Lacques

Cola Ben

Heranese Ghesk

Color Glone Exint net

10
12
72
7
75
15
15

BR

TI:

pasead

parsed

8:

passed

$6 \mathrm{H}$

passed

5i pased

soft pasced

$\begin{array}{ll}\text { Olear } & \text { falx } \\ \text { alear fair } \\ \text { olear feir } \\ \text { Ilght good-t } \\ \text { IIght good } \\ \text { tan good } \\ \text { tan }\end{array}$

pasated

passed

passed

ilght good-t pasiod

11 ght

passed

oloar

6004-5

good-5

falr

elear

falr

passed

th

$6 n$

passea pas sea falled pasted

-loar

falr

falled

3 H

passed

olear

good

pased

pas act

pas aed

passea

pas oed

cood

falled 


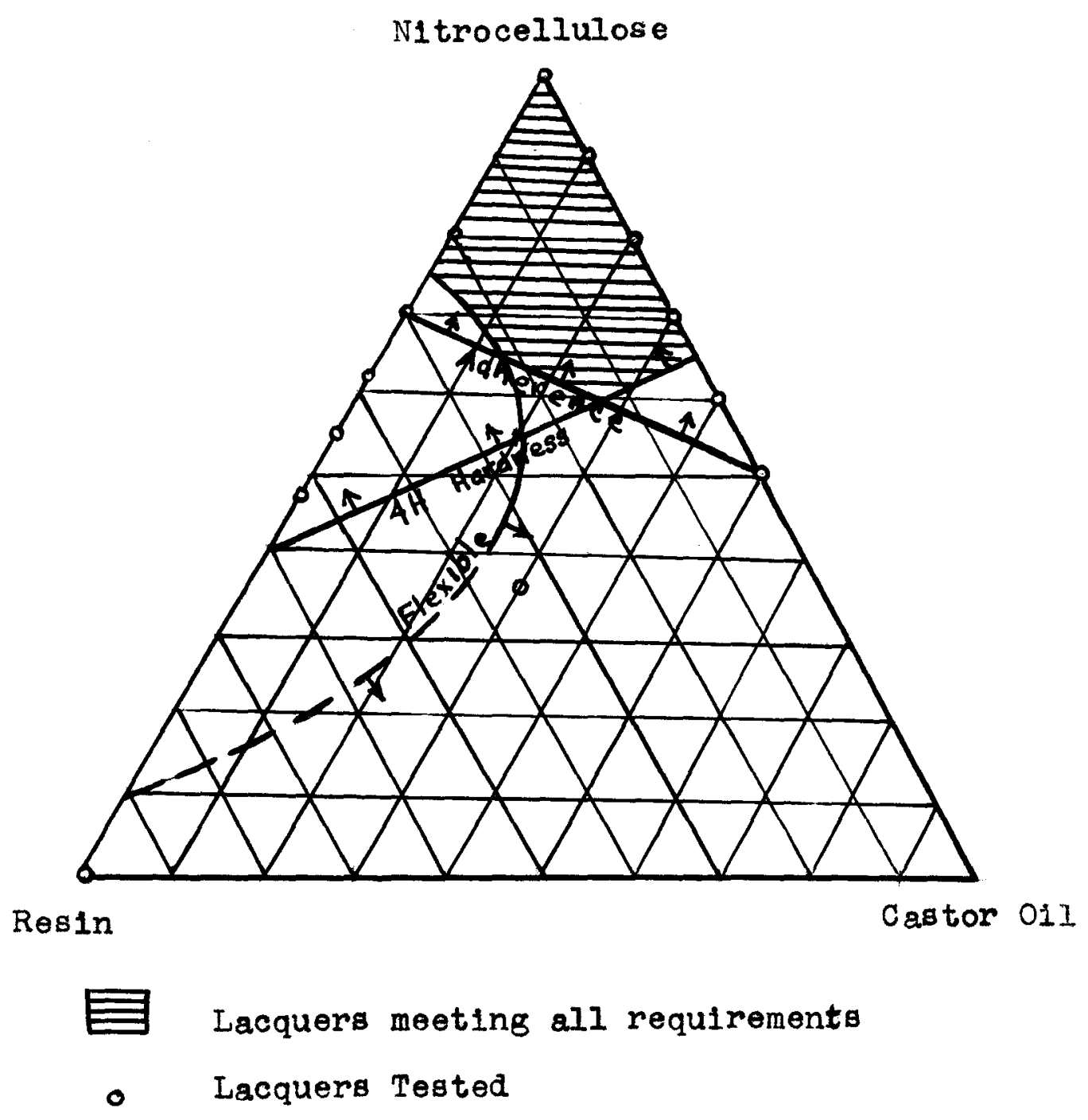

FIGURE 6

Lacquer Properties vs. Lacquer Formulation

30.3 Wt. \% Resin 


\section{TALS VIII}

Inoquor Froportios ve. Laequer Componition

38.1 W. 4 Realn

\begin{tabular}{|c|c|c|c|c|c|}
\hline $\begin{array}{l}80-0 \\
80-10 \\
80-20 \\
80-30 \\
80-40 \\
80-50 \\
80-60 \\
80-70 \\
80-90 \\
80-100\end{array}$ & $\begin{array}{r}0.0 \\
10.0 \\
20.0 \\
30.0 \\
10.0 \\
50.0 \\
60.0 \\
70.0 \\
90.0 \\
100.0\end{array}$ & $\begin{array}{r}100.0 \\
90.0 \\
80.0 \\
70.0 \\
60.0 \\
50.0 \\
40.0 \\
30.0 \\
10.0 \\
0.0\end{array}$ & $\begin{array}{l}0.0 \\
0.0 \\
0.0 \\
0.0 \\
0.0 \\
0.0 \\
0.0 \\
0.0 \\
0.0 \\
0.0\end{array}$ & $\begin{array}{l}\text { good } \\
\text { goed } \\
\text { good } \\
\text { falr } \\
\text { fatr } \\
\text { poor } \\
\text { poor } \\
\text { poor } \\
\text { port } \\
\text { gort }\end{array}$ & 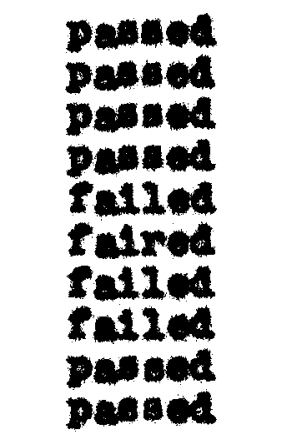 \\
\hline $\begin{array}{l}010 \\
020 \\
050 \\
010 \\
050 \\
060\end{array}$ & $\begin{array}{l}0.0 \\
0.0 \\
0.0 \\
0.0 \\
0.0 \\
0.0\end{array}$ & $\begin{array}{l}90.0 \\
80.0 \\
70.0 \\
60.0 \\
50.0 \\
40.0\end{array}$ & $\begin{array}{l}10.0 \\
20.0 \\
30.0 \\
40.0 \\
50.0 \\
60.0\end{array}$ & $\begin{array}{l}\text { good } \\
\text { good } \\
\text { good } \\
\text { rall } \\
\text { fall } \\
\text { poor }\end{array}$ & 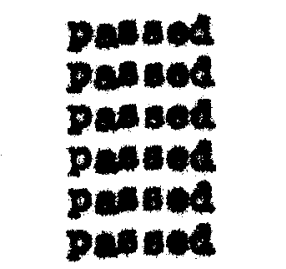 \\
\hline $\begin{array}{l}20 \\
\frac{11}{12} \\
13 \\
13 \\
15 \\
16\end{array}$ & $\begin{array}{l}30.0 \\
32.0 \\
20.0 \\
33.0 \\
35.0 \\
30.0 \\
40.0\end{array}$ & $\begin{array}{l}50.0 \\
\$ 8.0 \\
60.0 \\
33.0 \\
35.0 \\
60.0 \\
50.0\end{array}$ & $\begin{array}{l}20.0 \\
20.0 \\
20.0 \\
34.0 \\
30.0 \\
10.0 \\
10.0\end{array}$ & $\begin{array}{l}\text { poor } \\
\text { falt-p } \\
\text { fall } \\
\text { falr-s } \\
\text { ratr } \\
\text { good } \\
\text { good }\end{array}$ & 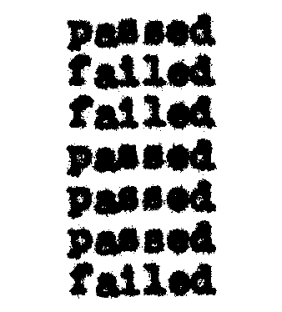 \\
\hline $80-40$ & 40.0 & 60.0 & 0.0 & falr & salied \\
\hline $\begin{array}{l}10010 \\
10020 \\
10090 \\
10070 \\
10050\end{array}$ & $\begin{array}{l}10.0 \\
10.0 \\
10.0 \\
10.0 \\
10.0\end{array}$ & $\begin{array}{l}80.0 \\
70.0 \\
60.0 \\
50.0 \\
70.0\end{array}$ & $\begin{array}{l}10.0 \\
20.0 \\
30.0 \\
10.0 \\
50.0\end{array}$ & $\begin{array}{l}\text { good } \\
\text { good } \\
\text { rall } \\
\text { poox } \\
\text { good }\end{array}$ & $\begin{array}{l}\text { poseod } \\
\text { blight } \\
\text { powed } \\
\text { posged } \\
\text { falied }\end{array}$ \\
\hline
\end{tabular}




\author{
TABLE VIII $\left(\operatorname{con}^{\prime} \$\right)$ \\ Laoquor Properties ve. Leequer Compontten \\ 38.1 w. 1 Reoln
}

Lamace

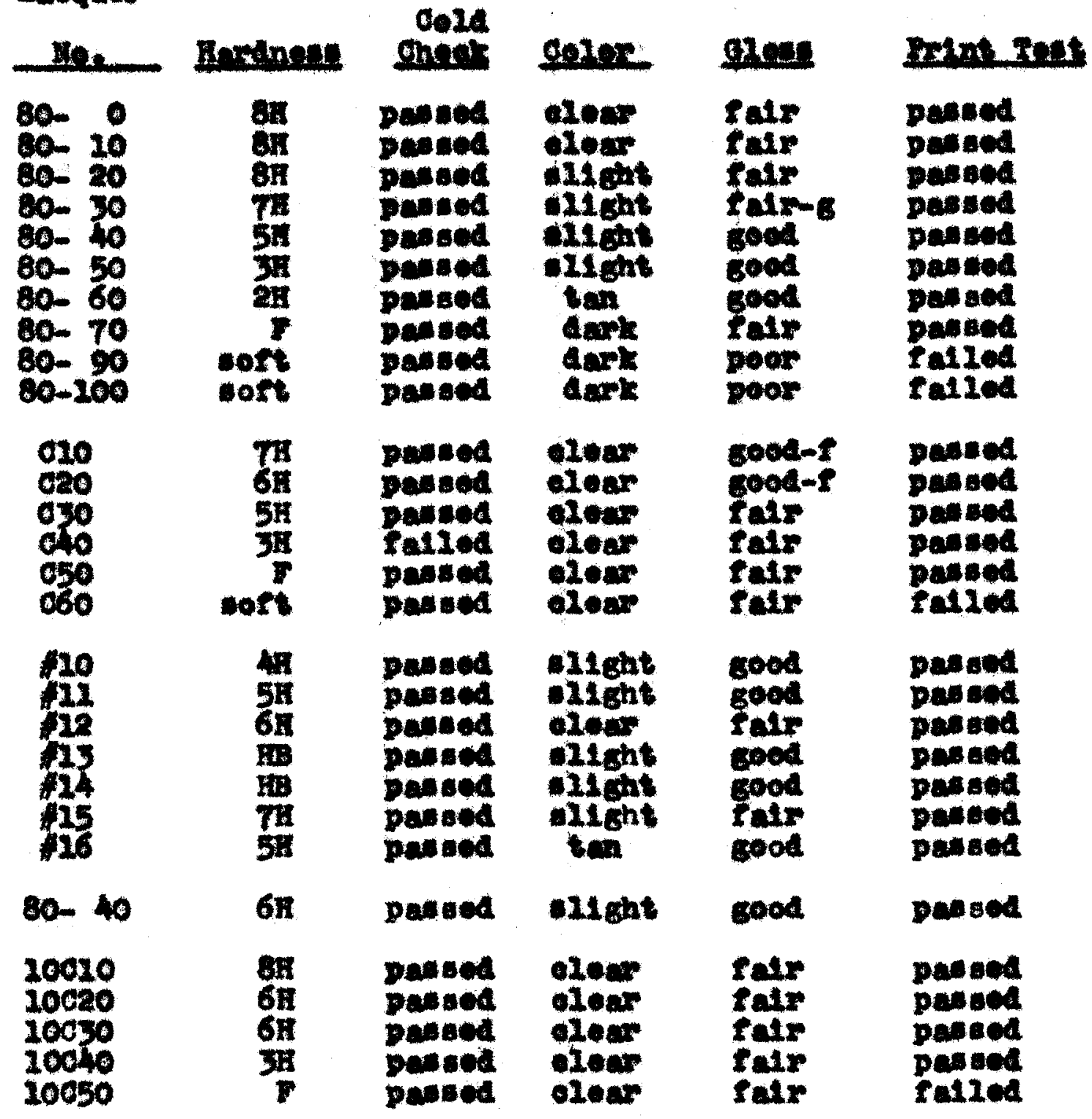




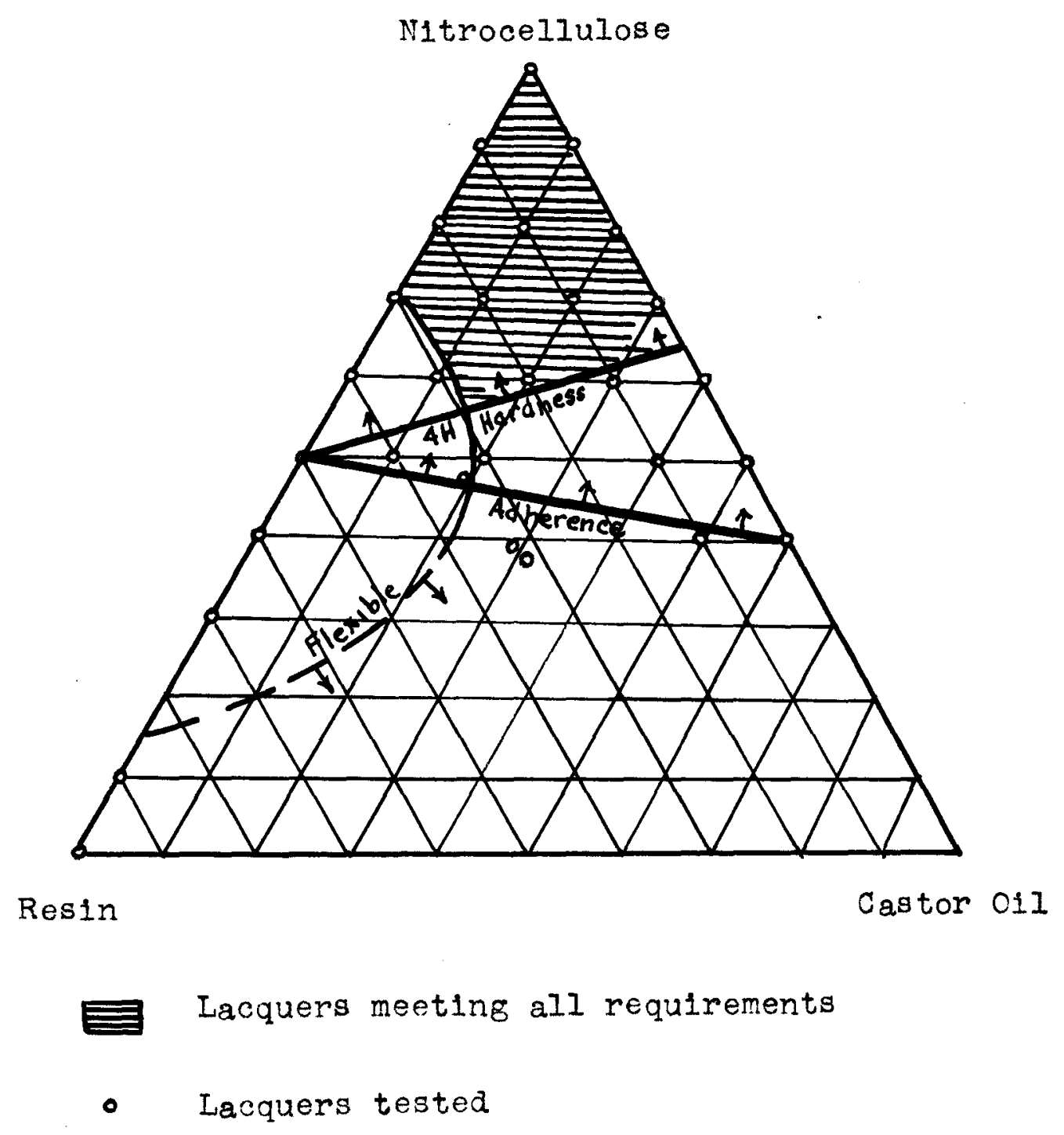

\section{FIGURE 7}

Lacquer Properties vs. Lacquer Formulation

38.1 Wt. \% Resin 
TARTBH:

4. a mane of cotermining the usablity of tho roalus in varnithec, it was dooled to ook the reaina into

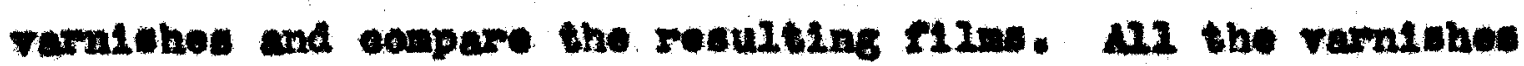

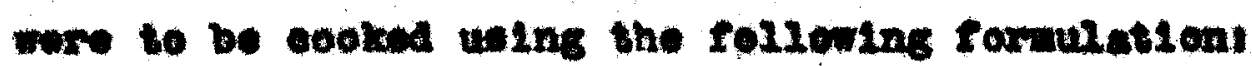

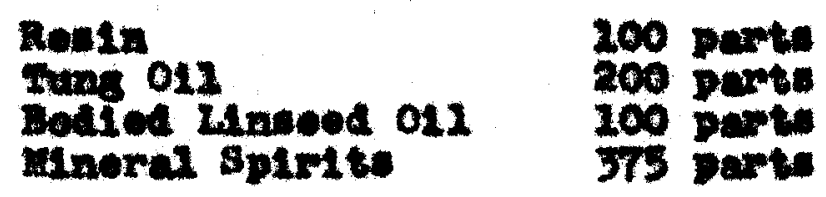

The realn wat dispored late the tung o1I and noated to $275^{\circ} \mathrm{C}$, then to $260^{\circ} \mathrm{O}$ in ten minutes, and to $295^{\circ} \mathrm{O}$ In ten more minutes. The bedied IInsoed oll was edded to Gill back the resetion and the aixture was thinned with min-

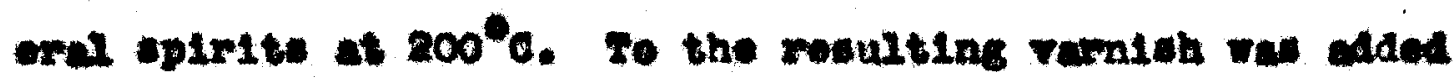
arlore In the following proportion, based on the oll,

$$
\begin{aligned}
& \text {.0ax eobalt motal amer } \\
& .10 \% \text { mengenese notal arier } \\
& .50 \% \text { leed netar arrex }
\end{aligned}
$$

The resinn were not oll coluble and other mothods had to be rosorted to if the rosin were to bo utilised. Difricalty vas eacunterod in the Mepersion of the rosin into the tung 011. For hoot would not disperes the solla rouln inte the 011. Eren in tho oase of the resine whioh rould wult the soc affloulty wo onountored, for after the ramiah wo cooked and thinned, the realn wouzd be found in wall pleces on the botton of the ramien rottle. It was thought that orinding the resin very finely inte the 012 before 
hoating alght ouve alsperston, but this aleo falled.

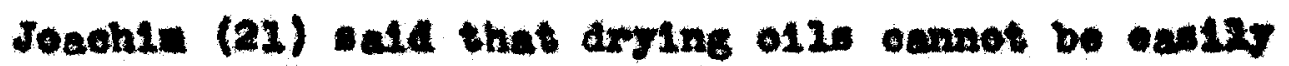
Inecrporated wth glyoerol phthalate. Nore addition of a

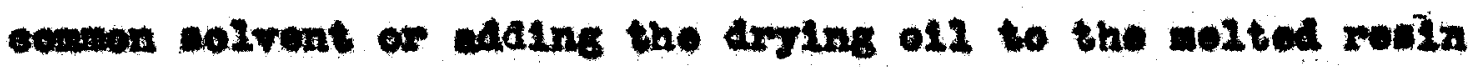
was not curfielont. To combine arying olis alreotis high semperatures are reached to in an antedare or lons resetlone through the wes of blgh boliting 11 quide.

B11: (24)(1) also stated that arying o11s oamnot be blmat with phthello elyoerlde by werely mixing in a bonwen wolvat or by waing the olle alrootly to the rused resin. Mon a arying oll wa hoated with a mxture of phthalle glycomde elyomel, the combination of the oll oocurred so diung that the resin wually gelled before the realn reacted. Hewever alyeorel phthalate would be combined wh a drging 011 in any proportion by hoating the tro in the prosence of a high bolling colvent. For oxemplo, when ture oll wa heated with a colution of phthalle glycoride in bensy banso-

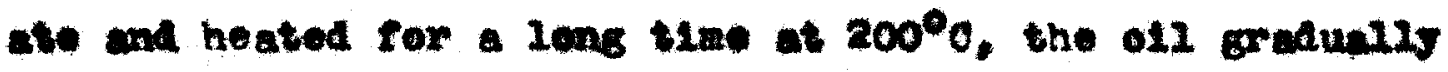
thiokened and rinaily diepored inte the rosin. Upon romoval of the solvent by alstiziation a product of the roeln and arying oll was obtatnot.

An attempt was waie to almperse the realn into the teng oll using tetralin a the hich bolling eolvent and beating the mixture for a long time at $200^{\circ} \mathrm{C}$. In wah oese 
1t wa found that upon aldtiling the solvent oft that the reain had not complotoly diaporad inte the oll and ocnuequcnt15 oould not bo used in oorrolating dath on varnithos sooked weing these rosins. It was apparont, howover, that the rosins wh the greator modifloation wore more oaslig diepersed but would not aloporwe completely oren with long cooking.

In a study of the varlou modiried alkg resins uned in raxnith produotion, it wa found that the great andor165 of thew wore modified with drying, boul-drying, ow nomarying 0115. or the fatty cold of those olll. Inoorporation of a definite smount of o1I Into the rosin was nocessary in ordor to make 1 eolublo in 012 and suttable for varnioh une.

Because of the diffiouity of dieporaing the modified realne inbe the tung o11, It wa unilkely that the sulfonated aloohol modifled remin could bo applied in varnioh sanufaoture. The rouln might be modified with some o11 along with the wifonated aleohol to make $1 t$ oll coluble, but that was bogond the soope of this thesis, whtoh doall only with the puxe oudronuted eleohol alkgi roein. 


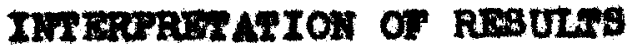


A survey of the data on the modifteation of the alkg reain by the oulfonated aloohol indeated that the incorporation had a cortening and plabtetaing afrect in the resinf the efreate beconing more notheodble on the modirleation we Ineroused. This plastifleation had bon cocompated by on Inowease in osterifleation, dearease in opeolflo granty deorease in sold number, deorease in hartness, inorease in colub111ty. and gredual darkenter of the oolor of the rodin as the wesin wore furthor modifled with the aulfonated alconol.

By far the moot Iaportant result of the medifioation

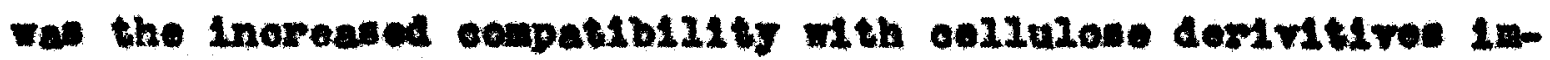
parted of the sulfonated aloohol, produclng realn sultable fer une in lacquer fommiation.

The Iadqurs formed from the modifled realni proved to noet most of the epectritation roquirod for a uble 100quer. These preperties have been plotted of the enolosed trilinear charte, and the properties of any formulation of rosin, nitrocollulose, and oastor 011 can be found by reforIns to that point on the chart. One diagdrantage of the Iequers was the 11 ght brom oolor $1 \mathrm{mparted}$ by the rosin, but the glose was good, and thoy nould be sultable fer pignented laoquer I1Ine. The result of the laoquar work oan best be exprossed by the use of the rollowing trilinear diagxims 
FIOURE

Variation of Laoquer Proporties

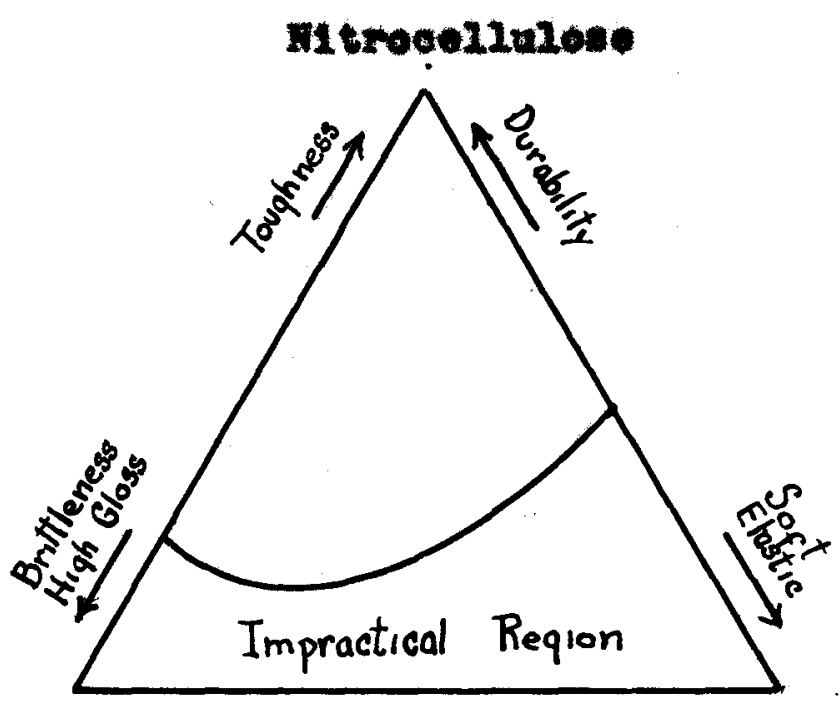

Resin

Castor ot2

The reoulting sulfonoted aleohol modifled rosin:

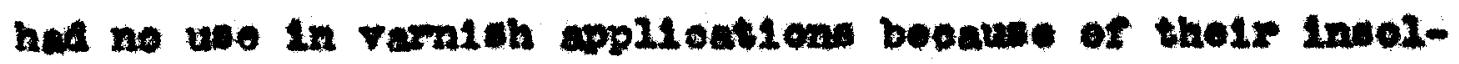
ub11165 in ramiah olis. 


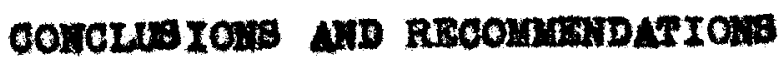


A number of effeote were apparent as the alkps ro-

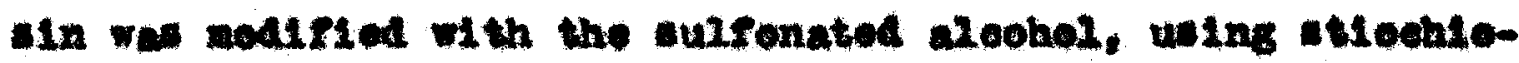

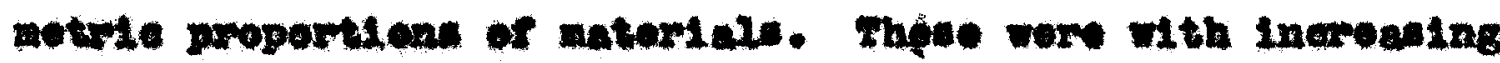
modirtoatlon:

1. Inerease in ostorifleation before thi ekming

2. Dooneser in aela mumber

3. Dearvate In apeelf1, eraity

4. Inerose in wolubi218y

5. PLestifleatien of the woiln

6. Inoreaned cookting tive ot the some temporature

7. Gradual dextentng of the rodin

8. Ineroaged compatibility with nitroceliulose maklng powalble the use of the rooins in nttrocolituose leoquer formulation.

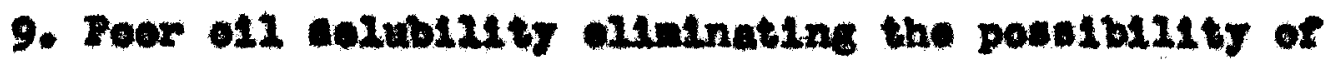
varalen applioatlon.

Gonereily saturatod ratty acld modified alkyd rowin 1sequors are suporior in ahoronoe, toughnes", and resiotence to olls und aleohel. (29). They form leoquers of exeeptional curlb111ty on expesure to wather. Further wark could posably be done on prolonged weathering tesse to oheex the analogy betwen the suztonated aleohol modiftod alkyd ronis laoquere and the fatty and modifled resin 1aoquers. 
74

ITEXR MTURE OTFWD 
(1) Many, I. V., U. B. Pat. Mo. 2,893,874 2933

(2) Arsem, W111an C., Canadlar Rat. To 322,2661932

(3) Arsea, WL121an 0., 0. S. Pat. Ho. 1,098,776 2924

(4) Barry, 7. Healy, Ind. Hns. Chom. 4, 53-56 (1928)

(5) Brubaker, Moriln M., Brit. Pat. Ho. 422,8451935

(6) Brubalox, Moriln X., 0. 8. Fat. Ho, 2,035,528 1936

(7) Bmbaker, 1. H., and Graves, O. D., 0. S. Pat. No. $1,995,828 \cdot 1955$

(8) Gallahan, H. J., 0. 8. Pat. Mo. 1,108,332 1924

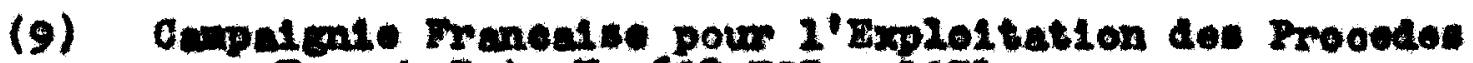
Fronot Pat. No 698.795 1931

(20) Carawall, Thowas 3., U. S. Pat. No. 1,924,396 1933

(11) Genorer, 0. S. Fat. No. 1,678,105 1928

(12) Conorer, 0. S. Fat, No. 2,592,082 1926

(13) 0oolldge, 0010, 0. S, Pat. Ho, 2,059,050 2936

(14) Ell1, "The Onealetry of synthosle Rosin" V02. II - 866 Nom York Retnhold Publithing co. (2955)

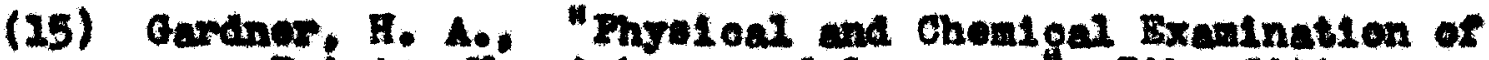
Fainte, Varnishes, and Lacquers 5 th edition Inistives of Paint and Varnith Roseareh. Nabhingtea, D. C. (1932)

(16) Hex, Molf, 0. s. Fat. No. 1,947.416 1933

(27) Arrage, Shigeru on Ohath, K111nosula, J. soe. Chon. Ind. Japan 41 supplowentry binding pp 90-91 (1959)

(18) Hone1 Kunvetesex 35, 76,109 (1931)

(19) Hopklns and nopornots 0. 8. Fat. Ho. 1,974,742 2934

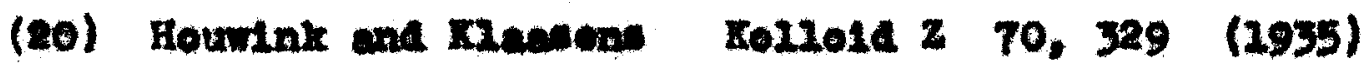


(21) Jonohin, Beajanip, "Apouted Patnt and Varnith Onvalient vol. II p 247 St. Loule, Lo.. Darioen ratut Jourad Co. (1937)

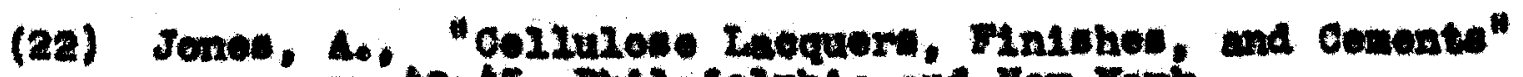
pp 40-45 Philedelphis and Mow Torit J. B. Uppeneott 00. (1937)

(23) K1enle, R. H., In. Ing. Onem. 22, 590 (1930)

(24) Xlonie and Furguson Ind. Bag. Chom. 22, 349 (1929)

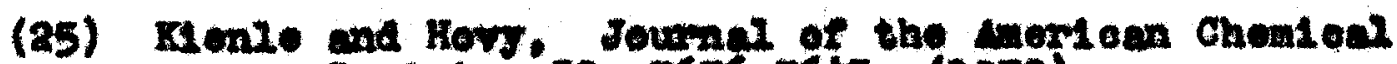
Bootety 59, 363-3645 (2930)

(26) Kienle and How. Journal of the Ameriou Chomical Bouloty 51. 509 (29a9)

(27) Klenio and Rohles 0. S. Pat. No. 1,097,260 2933

(ae) Kunie, R. H., O. S. Rat. No. 1,695,566 1928

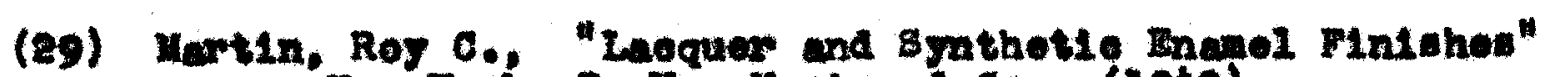
Her York D. Van Nostrund Co. (1940)

(30) Rowenblun, Isceal, v. 8. Pat. No. 2,088,612 1937

(31) Bohzenter Brit. Ohen. Abstreat B 1933257 (2933)

(32) Salth, Watten, J. Soe. Ohem. Ina. 20, 1075 (1902)

(33) "Etheeel" Bulletin publimod by Den Chemical co.

(34) German Pat. No. 583,164 2934 


\section{somornmager}

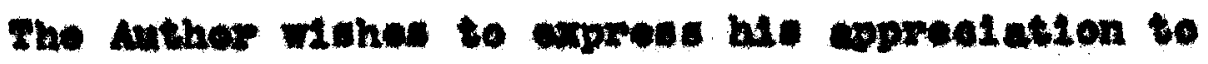
the Louintize 012, Palat, and Vaniel Froduotion olub for

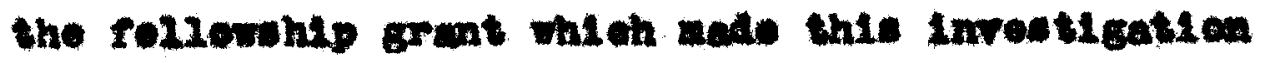
pencerbe.

75. alse withe to thent the Colgete Palmalive Peet 6. and the Brooter and Guble Co. whe oupplied emples of

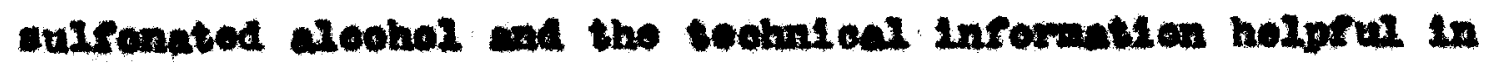
thie researob. 


\section{VIrA}

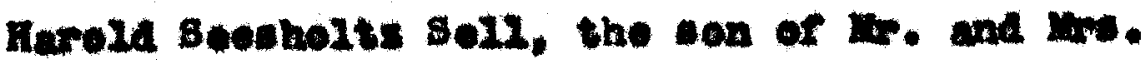

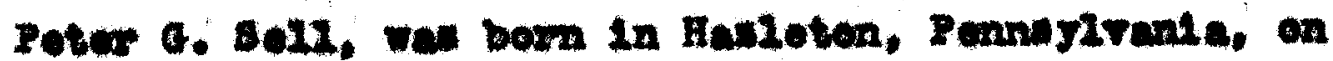

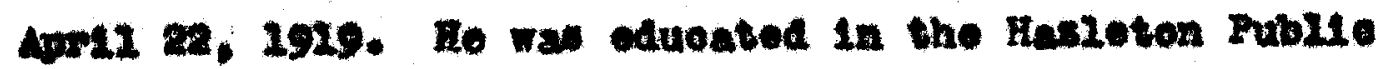
Babole and coduated Irow the Faneton Sonter Fl gh Sohod en June 27, 1936, wth a Colloge Froparatory Diplowa. While In high sohoel he we a nciber of the National Sehelastlo Honor seatetr.

Bpen h10 geatuation froe high sobool he entered The Ponngrival, Itate College, graduating an June 20, 1940,

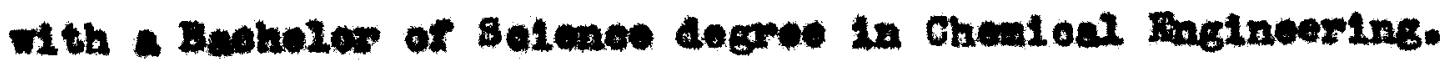

If wo wardod the Leuturi2le Ratnt, 012, and Varnion Glub Followaty at The spoed solentifte Sohool of

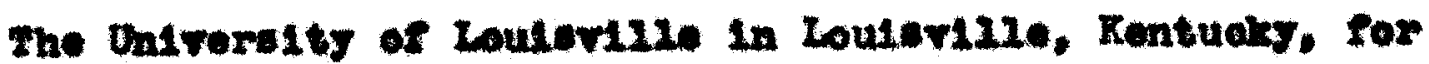
groduate atuky in paint tedmolos for the jeat $1940-41$. the oraduate study Ioding to the docree of Master of Oneat ead Ratinoentng.

nie craduate thesie was "the use of Surronated

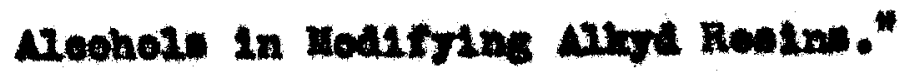

Upen graluation wa Jue 3, 1942 he will enter the

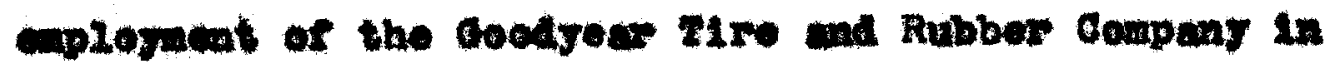
Area, onle. 